\title{
An in vitro 3D bone metastasis model by using a human bone tissue culture and human sex-related cancer cells
}

\author{
Francesca Salamanna ${ }^{1,2}$, Veronica Borsari ${ }^{1}$, Silvia Brogini ${ }^{2}$, Gianluca Giavaresi ${ }^{1,3}$, \\ Annapaola Parrilli ${ }^{1}$, Simona Cepollaro ${ }^{2,4}$, Matteo Cadossi ${ }^{5,6}$, Lucia Martini ${ }^{1,2}$, Antonio \\ Mazzotti ${ }^{5,6}$, Milena Fini ${ }^{1,2}$ \\ ${ }^{1}$ Laboratory of Biocompatibility, Technological Innovation and Advanced Therapy, Rizzoli RIT, Rizzoli Orthopedic Institute, \\ Bologna, Italy \\ ${ }^{2}$ Laboratory of Preclinical and Surgical Studies, Rizzoli Orthopaedic Institute, Bologna, Italy \\ ${ }^{3}$ Laboratory of Tissue Engineering-Innovative Technology Platforms for Tissue Engineering, Rizzoli Orthopedic Institute, \\ Palermo, Italy \\ ${ }^{4}$ Department of Medical and Surgical Sciences, University of Bologna, Bologna, Italy \\ ${ }^{5}$ I Orthopaedics and Trauma Clinic, Rizzoli Orthopaedic Institute, Bologna, Italy \\ ${ }^{6}$ University of Bologna, Bologna, Italy
}

Correspondence to: Veronica Borsari, email: veronica.borsari@ior.it

Keywords: 3D model, cancer-bone metastasis model, human bone tissue, human sex-related cancer cells

Received: November 02, 2015 Accepted: September 27, $2016 \quad$ Published: October 19, 2016

\section{ABSTRACT}

One of the main limitations, when studying cancer-bone metastasis, is the complex nature of the native bone environment and the lack of reliable, simple, inexpensive models that closely mimic the biological processes occurring in patients and allowing the correct translation of results. To enhance the understanding of the mechanisms underlying human bone metastases and in order to find new therapies, we developed an in vitro three-dimensional (3D) cancer-bone metastasis model by culturing human breast or prostate cancer cells with human bone tissue isolated from female and male patients, respectively. Bone tissue discarded from total hip replacement surgery was cultured in a rolling apparatus system in a normoxic or hypoxic environment. Gene expression profile, protein levels, histological, immunohistochemical and fourdimensional (4D) micro-CT analyses showed a noticeable specificity of breast and prostate cancer cells for bone colonization and ingrowth, thus highlighting the speciesspecific and sex-specific osteotropism and the need to widen the current knowledge on cancer-bone metastasis spread in human bone tissues. The results of this study support the application of this model in preclinical studies on bone metastases and also follow the $3 R$ principles, the guiding principles, aimed at replacing/reducing/refining (3R) animal use and their suffering for scientific purposes.

\section{INTRODUCTION}

Bone metastasis is a common finding in the natural history of several types of cancers and contributes extensively to morbidity and mortality in cancer patients [1-2]. After the identification and emergence of the 'seed and soil' [3] and the 'vicious cycle' concepts [4] numerous studies have been performed to understand the complex interaction between metastatic tumor cells and bone. The tumor cells that metastasize in the bone induce destructive osteolytic and/or bone forming osteoblastic lesions [4] and 'teach' this affected bone microenvironment to produce factors that stimulate tumor cell growth [5-6]. To understand the cellular and molecular mechanisms involved in cancer-bone interaction and metastasis treatment, reliable models are required to mimic the biological processes that occur in patients.

To date traditional cancer bone metastasis models (in vitro and in vivo) contain inherent limitations concerning controllability, reproducibility and flexibility 
of design. Conventional 2D cell culture models have provided a better understanding of the ability of tumor cells to grow, but they do not provide information about the complex interactions between the cancer cells and the physicochemical environment that exists within living tumors [7]. Such limitations may offer less reliable data thus leading to restrictions for translation into clinical application. In vivo animal models are more suitable and overcome many of the limitations of the 2D model, but their inability to accurately mimic human cancer-bone metastasis, combined with the need to study metastases under controlled conditions, has led to the emergence of alternative in vitro models based on 3D cell cultures. This new field of research lies at the intersection between pathology and tissue engineering by providing an important alternative to both complex in vivo whole organism approaches, and 2D culture with its spatial limitations [8]. Since advances in culture techniques have emerged from the field of tissue engineering, $3 \mathrm{D}$ cell culture methods have increased greatly in number [9-10]. In fact, biomaterials such as natural or synthetic matrices/scaffold (e.g. Poly (DL-lactic-co-glycolic) acid, Poly (Lactide-co-Glycolide), chitosan, alginate, collagen) ordinarily employed for engineering bone and cartilage tissue [11-14] have also been used for culturing cancer cells [15-6].

However, one of the main physiological approaches may be the culture of bone tissue explants that allow the 3D architecture, the tissue extracellular matrix and the cellular complexity to be preserved in vitro.

Nordstrand et al. implemented a murine calvarial explant to monitor how tumor cells influenced the bone remodeling process and how the bone microenvironment influenced the tumor cells [17]. To achieve this, they established a two-compartment in vitro co-culture and used it to follow the tumor-induced bone remodeling. Similarly, Schiller et al. developed a model where whole neonatal mouse femurs were co-cultured with a variety of mouse and human cancer cell lines and found bone tissue viability and described the synergistic paracrine interactions between intact bone and tumor [18]. Others studies have cultured mouse bones harvested from breast cancer xenograft models to examine the cytokine production of mouse bones colonized by breast cancer cells. These studies showed the feasibility of bone coculture models to stimulate the microenvironment and studied the dynamic cell interactions within the bone metastatic niche [19-20]. Furthermore, several studies of tumor biology have benefited from the hypoxia setting which mimics the nutrient and oxygen insufficiency at the tumor-host interaction [21]. Based on these findings, Curtin et al. [22] utilized a 3D cancer-bone metastasis model composed of free-floating live mouse calvarial bone organs in the presence of cancer cells in a roller tube system under hypoxic conditions. The study developed a $3 \mathrm{D}$ model which simulates closely the in vivo tissue under defined conditions. These 3D in vitro models, where human cells are cultured together with animal tissues, well mimic the in vivo condition, but leave out the considerable aspect of species-specific osteotropism. In fact, several authors [23-24] highlighted that human breast cancer cells preferentially home to human bone fragments implanted in mice, thus underlining the species-specific behavior. Nevertheless, to the present authors' knowledge there is a lack of 3D models with the use of human bone. The use of human bone and human cells would allow patient factors that influence the development of bone metastases to be studied, i.e. age, sex, concomitant comorbidity and unhealthy life style factors. Recently, Contag et al. [25] developed a co-culture model able to monitor dynamic interactions between human breast cancer cells and human bone tissue. The authors used a static model where the bone marrow was depleted from the bone tissue and cancer cell/bone interactions were evaluated during relatively short time periods (for up to 96 hours) and not in hypoxic conditions, which is typical of tumors grown in vivo.

For all these reasons, and taking into account the $3 \mathrm{R}$ principle aimed at reducing the use of laboratory animals and their suffering, a 3D bone metastasis model was developed. The in vitro 3D cancer-bone metastasis model was performed by culturing human breast or prostate cancer cells with discarded human bone tissue isolated from the femoral head after total hip replacement surgery, from female and male patients respectively. Hypoxia was also applied to the culture to reflect the in vivo conditions able to simulate the nutrient and oxygen insufficiency in tumor-host interaction. This study allowed to set-up an in vitro $3 \mathrm{D}$ sex-related bone metastasis model, able to recapitulate the different stages of breast and prostate cancer bone metastasis. This interactive system, through histological, immunohistochemical and 4D micro-CT analyses and by investigating specific markers predictive of bone remodeling, appears to be appropriate for the study of bone metastases.

\section{RESULTS}

\section{Bone tissue viability}

We studied cancer/cell bone interaction for relatively long periods for up 7 days, and the alamar blue test confirmed the bone organ viability (Figure 1A and 1B). At T0 both female and male femoral head specimens showed a high level of bone viability (Figure 1A and 1B). Bone viability was significantly higher at T0 when femoral head specimens were compared to those whose bone marrow was depleted through the liquid nitrogen treatment $(p<0.0005)$ (Figure 1A and 1B). The bone viability was also maintained after 7 days of culture in the TubeSpin Bioreactors on the rolling tube apparatus with and without cancer cells (MCF-7 and PC-3 respectively) 
and in both normoxic and hypoxic conditions without significant differences. When MCF-7 or PC-3 were cultured alone in the TubeSpin Bioreactors on the rolling tube apparatus significant differences between normoxic and hypoxic conditions, in both female and male femoral head specimens, were observed. In fact, as shown in Figure $1 \mathrm{~A}$ and $1 \mathrm{~B}$ both $\mathrm{MCF}-7$ and $\mathrm{PC}-3$ revealed significantly higher values in hypoxic conditions in comparison to normoxic ones $(p<0.0005)$.

\section{D micro-CT analyses}

The changes over time in bone volume fraction (BV/TV) and mineral density (BMD and TMD) parameters in response to $3 \mathrm{D}$ in vitro tumor cell culture is shown in terms of differences between the two experimental times (time 0 and 7 days) (Figure 2). No significant differences were observed among groups.

\section{ELISA protein assay}

The effect of MCF-7 and PC3 cells on bone fragments was investigated through evaluation of $\mathrm{OPG}$, RANKL, IL-1 $\beta$ and TNF- $\alpha$ expression. Results of significant data are summarized in the graphs reported in Figures 3 and 4. RANKL and TNF- $\alpha$ production was significantly increased in bone fragments cultured with MCF-7 breast cancer cells in comparison to bone fragments cultured without cancer cells, both in normoxic and hypoxic conditions (Figure 3). Conversely, OPG expression was significantly reduced in bone fragments cultured with MCF-7 cells compared to bone fragments cultured without cancer cells, both in normoxic and hypoxic conditions (Figure 3).

Bone fragments cultured with PC-3 cells showed significantly higher values of OPG and TNF- $\alpha$ expression compared to bone fragments cultured without prostate cancer cells, both in normoxic and hypoxic conditions, while IL-1 $\beta$ expression was significantly higher, only under normoxic condition (Figure 4). No significant differences were found regarding RANKL expression in presence of prostate cancer cells.

\section{Gene expression analyses}

The effect of breast and prostate cancer cell on bone fragments was investigated through gene expression analyses. Results are summarized in Figures 5 and 6 .

A Female bone organ culture viability
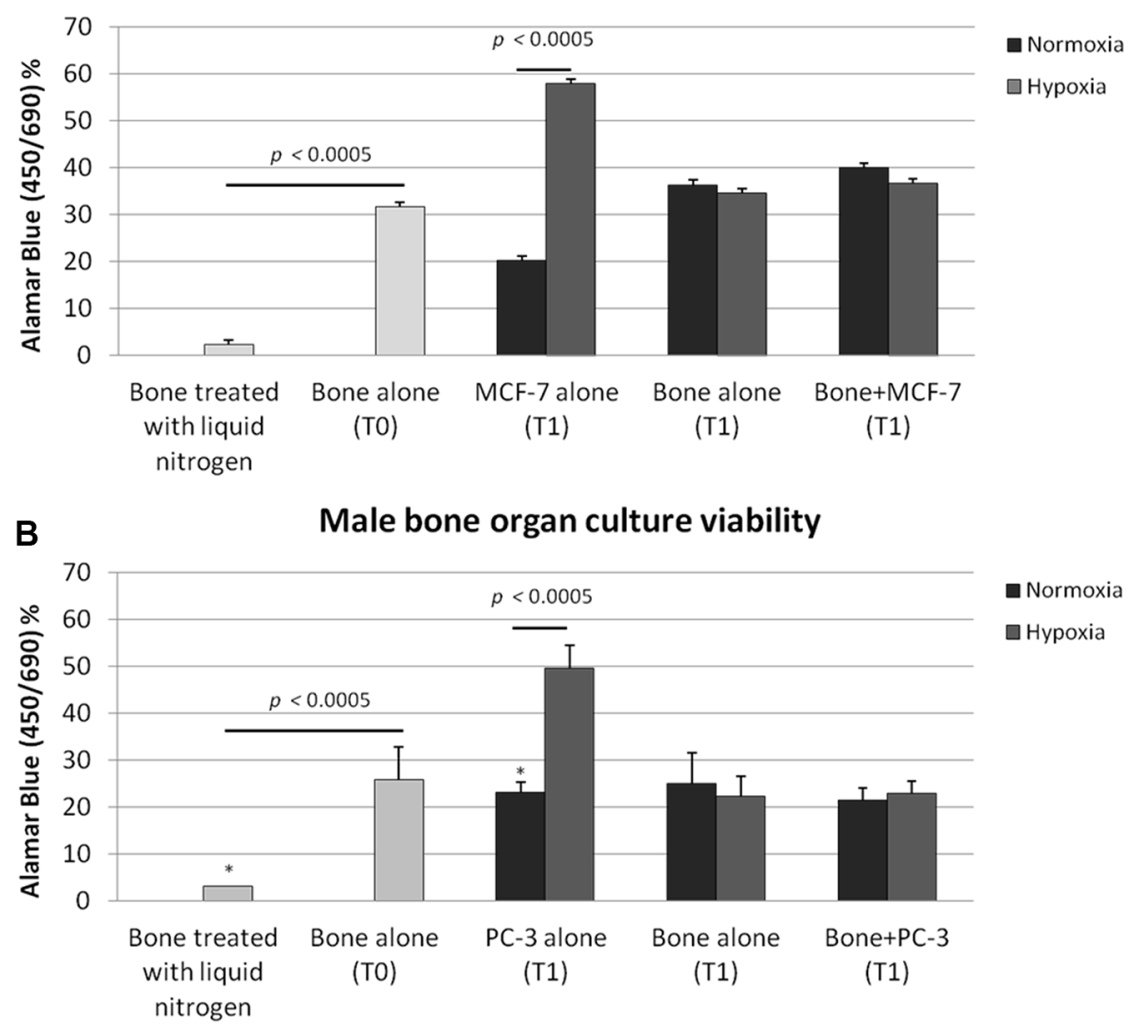

Figure 1: Bone tissue culture viability in (A) female and (B) male bone specimens treated with liquid nitrogen (necrotic bone, T0), in bone specimens alone (T0), in (A) MCF-7 and (B) PC-3 cultured alone in the TubeSpin Bioreactors in hypoxic and normoxic conditions (T1), in femoral head specimens alone (T1), in femoral head specimen co-cultured with $2.5 \times 10^{4}$ cancer cells in both hypoxic and in normoxic condition (T1). $T$-test analysis: ${ }^{*} p<0.0005$. 
Significantly higher values of RANKL, CTKS, PTH1R, IL-6, IL-1 $\beta$ and MMP-1 were found in bone fragments cultured with MCF-7 breast cancer cells in comparison to bone fragments cultured without cancer cells, both in normoxic and hypoxic conditions. Conversely, SPI1 and MMP-13 showed significantly higher values only under hypoxic conditions (Figure 5). Bone fragments cultured with MCF-7 breast cancer cells revealed significantly lower OPG expression in comparison to bone fragments cultured without MCF-7 (Figure 5). Bone fragments cultured with PC-3 prostate cancer cells revealed a significantly higher gene expression for RANKL, IL-6 and IL-1 $\beta$ compared to bone fragments cultured without cancer cells, both in normoxic and hypoxic conditions, while MMP-13 showed significantly higher values only in hypoxic condition (Figure 6). Significantly lower OPG gene expression was observed in bone fragments cultured with PC-3 compared to bone fragment cultured without cells, but only in normoxic condition (Figure 6).

\section{Histological and immunohistochemical analyses}

Femoral head specimens without cancer cells at T0 revealed typical trabecular bone architecture consisting of bone spicules (with osteocytes and osteoblasts) throughout the marrow compartment (Figure 7A). Marrow
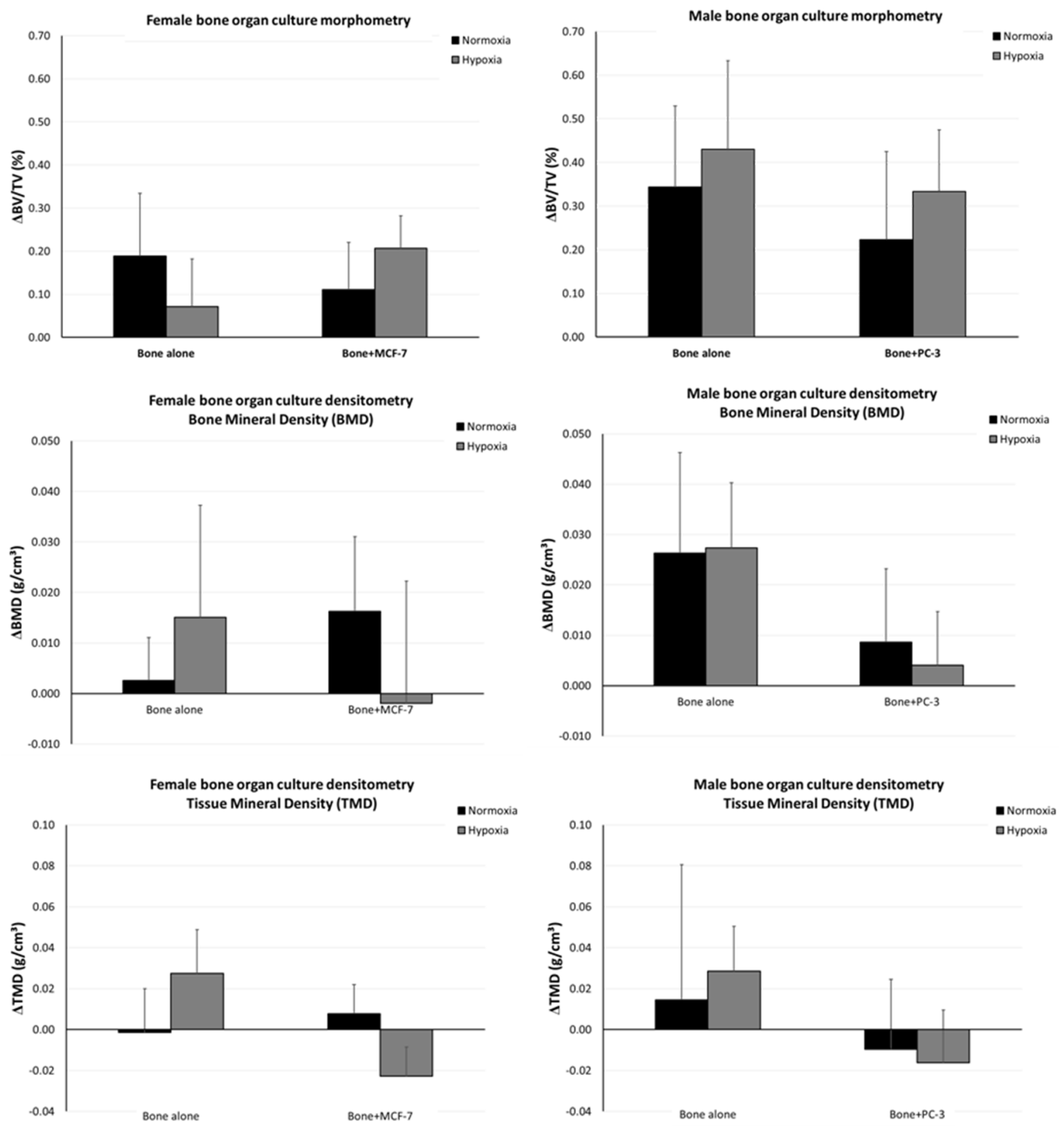

Figure 2: Changes over time in BV/TV and in BMD and TMD in response to 3D in vitro tumor cell culture. 

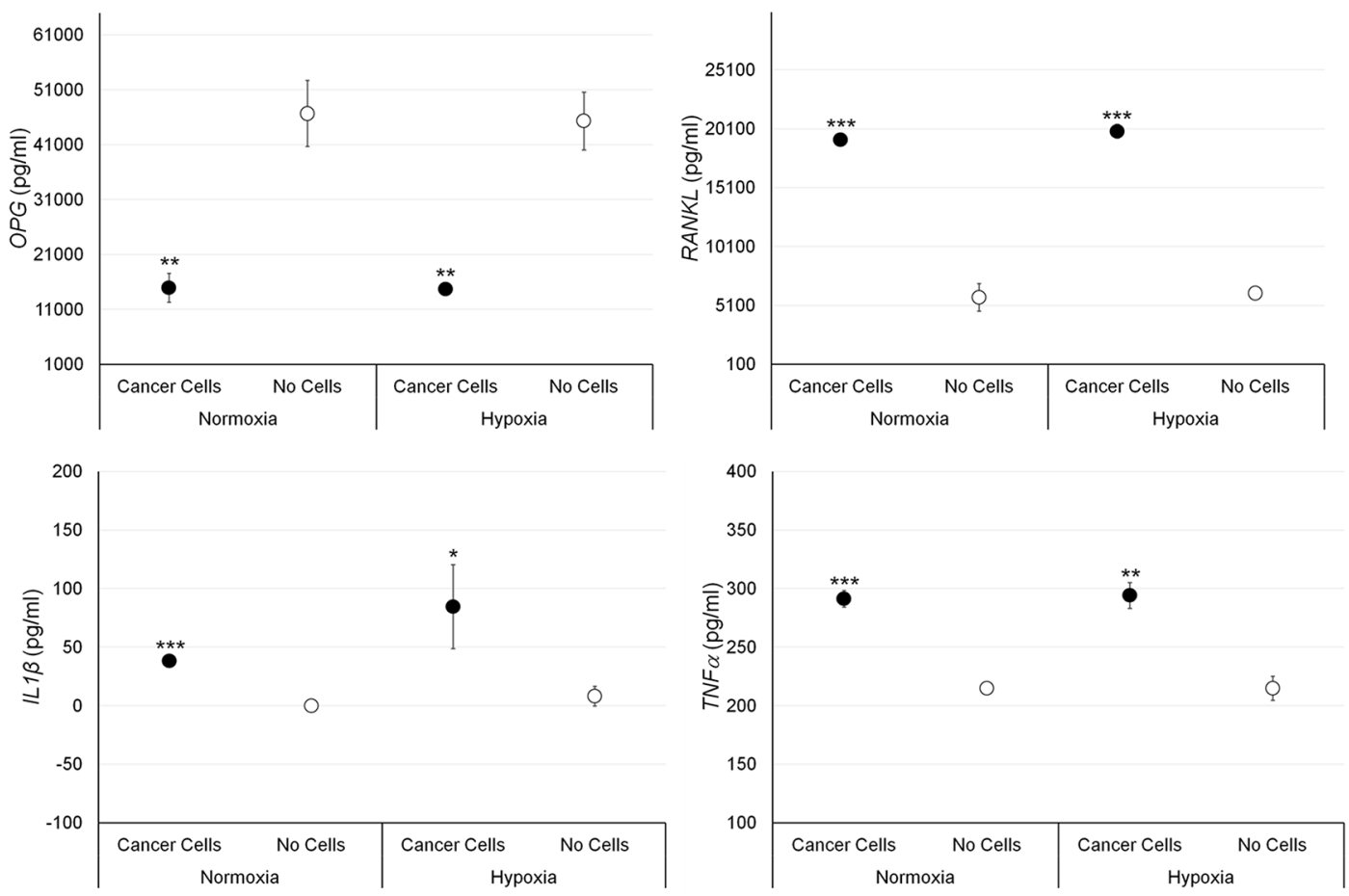

Figure 3: Protein releases (ELISA), expressed as total protein ratio ( $n=3$ replicates), in female bone fragments cultured with or without MCF-7 cancer cells, both in normoxic and hypoxic conditions. RANKL (normoxia and hypoxia $* * * p<0.0005$ ), IL-1 $\beta$ (normoxia: $* * * p<0.0005$; hypoxia: $* p<0.05$ ) and TNF- $\alpha$ (normoxia: $* * * p<0.0005$; hypoxia: $* * p<0.005$ ): bone fragments with MCF-7 versus bone fragments without cancer cells. OPG (normoxia and hypoxia $* * p 0.005)$ : bone fragments without cancer cells versus bone fragments with MCF-7.
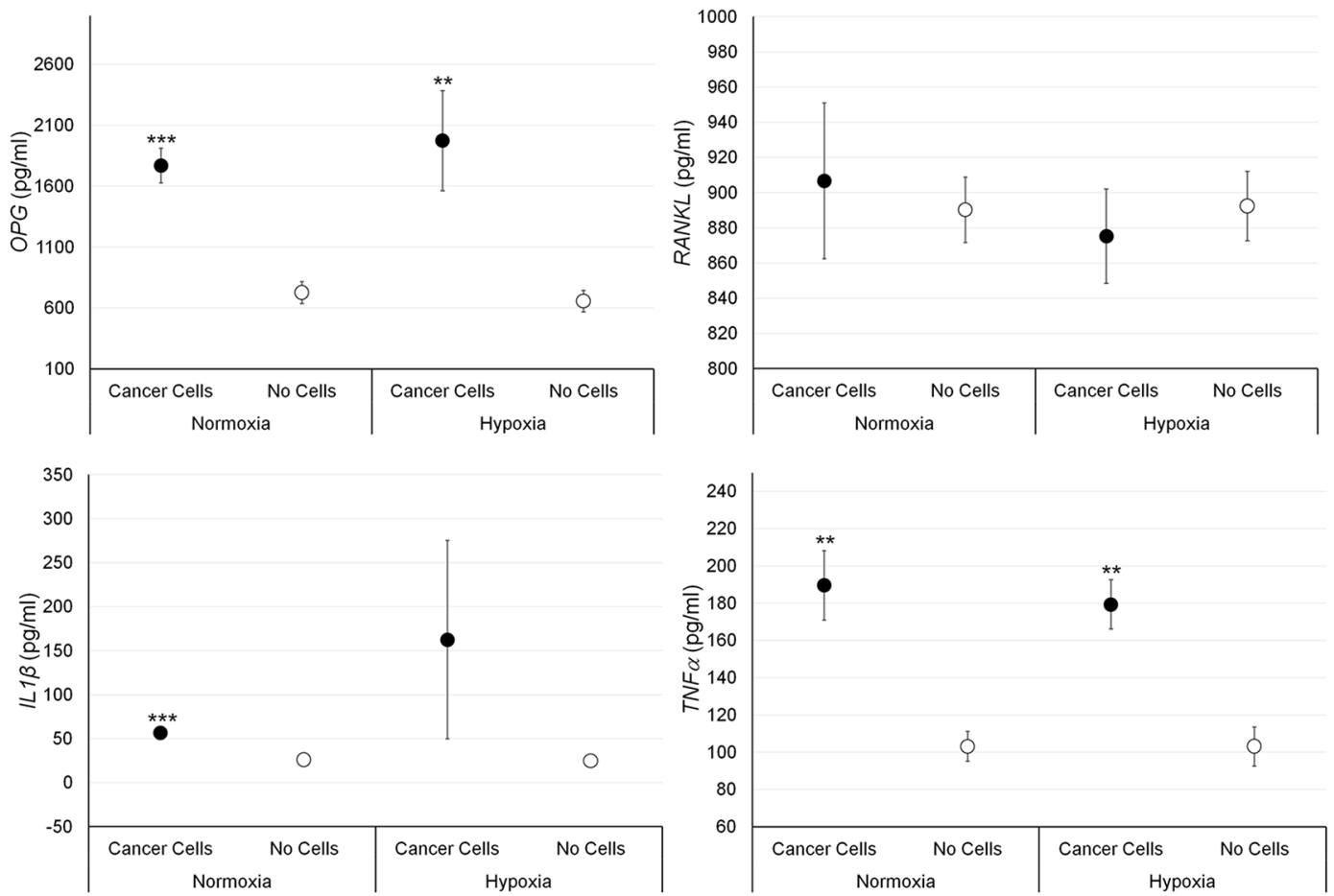

Figure 4: Protein releases (ELISA), expressed as total protein ratio ( $n=3$ replicates), in male bone fragments cultured with or without PC-3 cancer cells, both in normoxic and hypoxic conditions. OPG (normoxia: $* * * p<0.0005$; hypoxia: $* * p<0.005$ ), TNF- $\alpha$ (normoxia and hypoxia: $* * p<0.005$ ), IL-1 $\beta$ (normoxia: $* * * p<0.0005$ ): bone fragments with PC-3 versus bone fragments without cancer cells. 
cells including hematopoietic (red and white blood cell progenitors) and stromal cells (with numerous adipocytes) were present within the bone spicules (Figure 7A).

After 7 days of culture in hypoxic and normoxic conditions (Figure 7B and 7C) bone specimens maintained the same architecture and morphology as those at T0 (Figure 7A). In fact, bone trabeculae presented numerous osteocytes in lacunae and osteoblasts strictly associated to bone spicules (Figure 7B and 7C). As for bone fragments at $\mathrm{T} 0$ the presence of marrow cells and stromal cells with many adipocytes within the bone spicules was observed (Figure 7B and 7C).

Bone specimens cultured with cancer cells, MCF-7 or PC-3, under normoxic or hypoxic conditions, revealed an altered bone architecture and morphology compared to specimens cultured without cancer cells (Figure 8). Bone trabeculae were locally surrounded by malignant cells with tubule formations or solid cell clusters (Figure 8). Bone surface was at different phases of bone remodeling or different phases of bone resorption with, consequently, various morphological characteristics of the resorption lacunae. In addition, bone cell reaction varied from case to case. Morphological changes related to bone resorption included lacunar osteolysis and an initial trabecular fragmentation (Figure $8 \mathrm{~B}$ and $8 \mathrm{D}$ ). Additionally, in some cases osteocytes in the trabecular bone had disappeared leaving empty lacunae (Figure 8A and 10D). The altered architecture of trabecular bone may be ascribed to tumor cell and osteoclast activity as highlighted by the presence of osteoclasts along the trabeculae in bone specimens cultured with MCF-7 or PC-3 (Figure 8). In addition, infiltration in bone marrow spaces by malignant tumour, typically composed of foci of neoplastic cells with two or more hyperchromatic nuclei per cell, were observed in the specimens cultured with cancer cells, both MCF-7 and PC-3, under normoxic and hypoxic conditions (Figure 8). A histological analysis of the degree of bone resorption areas showed distinctions between different cancer cell types, MCF-7 and PC-3. In fact, in the specimens cultured with $\mathrm{PC}-3$, both under normoxic and hypoxic conditions, an initial osteoblastic activity with non-lamellar (fibrous-like) bone tissue formation, with presence of osteoblasts along the preexisting trabecule, was also seen (Figure 8C and 8D).

Post co-culture immunohistochemical staining with anticytokeratin 8 and 18 antibody of bone specimens with MCF-7 or PC-3, under normoxic and hypoxic conditions at 7 days, confirmed the histological results showing
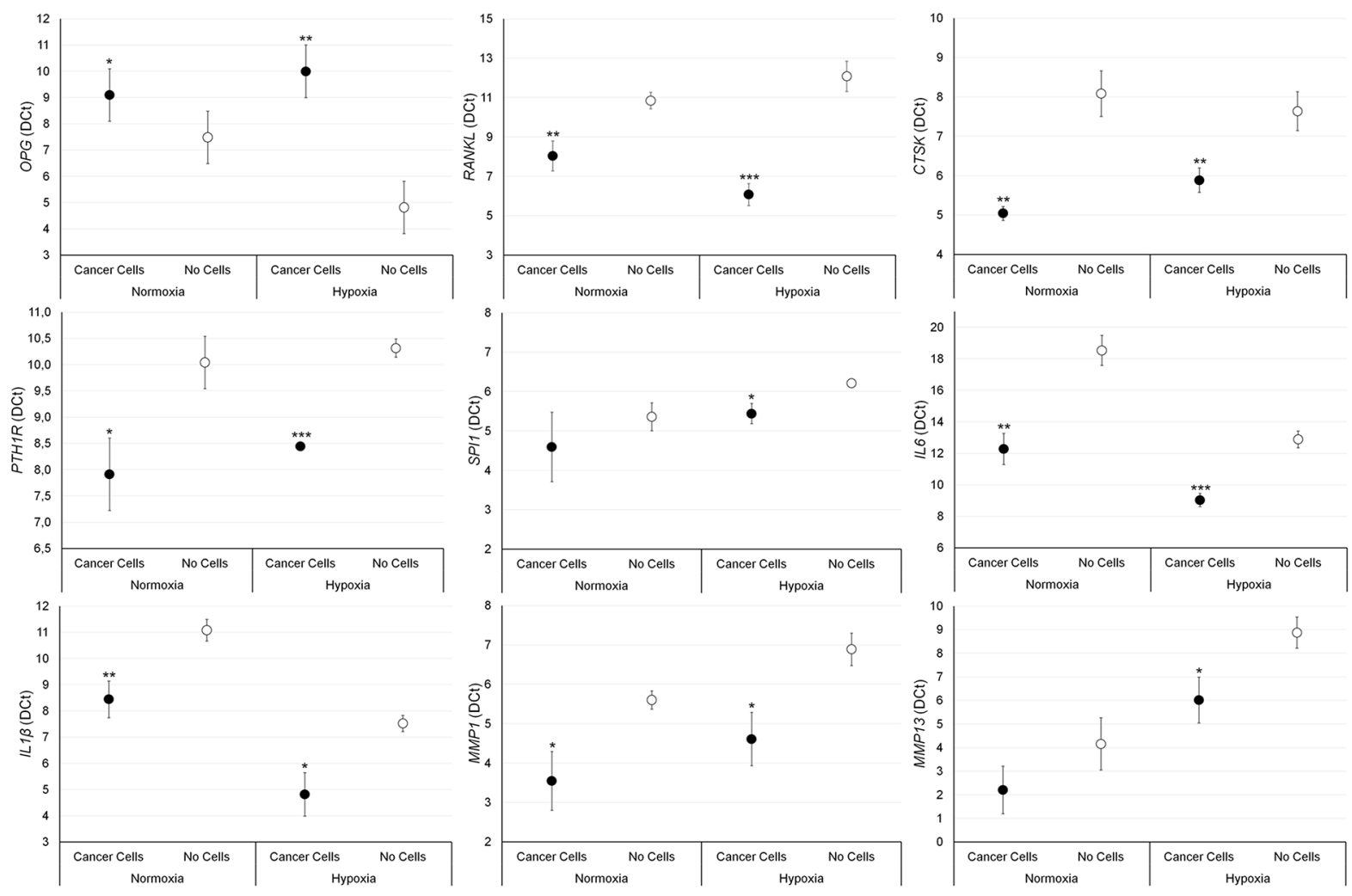

Figure 5: Gene expression analysis ( $n=3$ replicates) in female bone fragments cultured with or without MCF-7 cancer cells, both in normoxic and hypoxic conditions. RANKL (normoxia: **p $<0.005$; hypoxia: *** $p<0.0005$ ), CTKS (normoxia and hypoxia: ${ }^{*} p<0.0005$ ), PTH1R (normoxia: ${ }^{*} p<0.05$; hypoxia: $* * * p<0.0005$ ), IL-6 (normoxia: $* * p<0.005$; hypoxia: $* * * p<0.0005$ ), IL-1 $\beta$ (normoxia: ${ }^{*} p<0.005$; hypoxia: $* p<0.05$ ), MMP-1 (normoxia and hypoxia: $* p<0.05$ ), SPI1 (hypoxia: ${ }^{*} p<0.05$ ) and MMP13 (hypoxia: ${ }^{*} p<0.05$ ): bone fragments with MCF-7 versus bone fragments without cancer cells. OPG (normoxia: ${ }^{*} p<0.05$; hypoxia: $* * p<0.005)$ : bone fragments without cancer cells versus bone fragments with MCF-7. 
infiltration of tumor cells into the marrow compartment, predominantly in hypoxic condition, (Figure 9) and onto ossified bone surfaces.

Finally, TRAP staining after 7 days of culture with MCF-7 or with PC-3, both in hypoxic and normoxic conditions, revealed the presence of differentiated multinucleated osteoclasts throughout the trabecular bone (Figure 10A and 10B). However, a higher number of multinucleated active osteoclasts were observed in the specimens cultured with MCF-7 in comparison to those cultured with PC-3. Furthermore, the presence of a greater amount of differentiated multinucleated active osteoclasts was detected in the hypoxic condition.

\section{DISCUSSION}

Currently, with the growing acceptance of in vitro models as effective tools for studying cancer biology, many enhanced and novel 3D models have emerged in an effort to recapitulate the native tumor and its microenvironment [17-25]. We developed a 3D model of bone metastases using human bone tissue taken from total hip replacement surgery patients cultured with human breast or prostate cancer cells (MCF-7 and $\mathrm{PC}-3$ ) and established a "proof of concept" to recapitulate the bone metastasis and its microenvironment.
The main reason for the development of this dynamic $3 \mathrm{D}$ in vitro model was the need for a suitable model which would take into account the critical importance of the species-specific osteotropism that is essential in the study of bone metastases. The development of this model has a direct relevance in the study of bone metastases because it mimics more closely metastatic microenvironments in humans and provides a compromise between the reductionist approach which isolates cancer cells as a 2D monolayer, and the manufactured complexity of growing human tumors in xenogeneic hosts. Additionally, a model that so faithfully reproduces human metastases might be important to evaluate new therapeutic interventions to prevent and treat bone metastases.

The 3D cancer-bone metastasis model devised in this study was developed using a rolling apparatus system, where human breast or prostate cancer cells in suspension were cultured with free floating female and male human bone fragments, isolated from discarded total hip replacement surgery. The use of the rolling apparatus exposes equally all the surfaces of the human bone fragments to the cancer cells. In addition, to reflect the in vivo conditions we also took into account the hypoxic condition to mimic the nutrient and oxygen insufficiency at the tumor-host interaction. In fact, bone is a hypoxic microenvironment $\left(\mathrm{pO}_{2}\right.$ between 1-7\%) [26], which
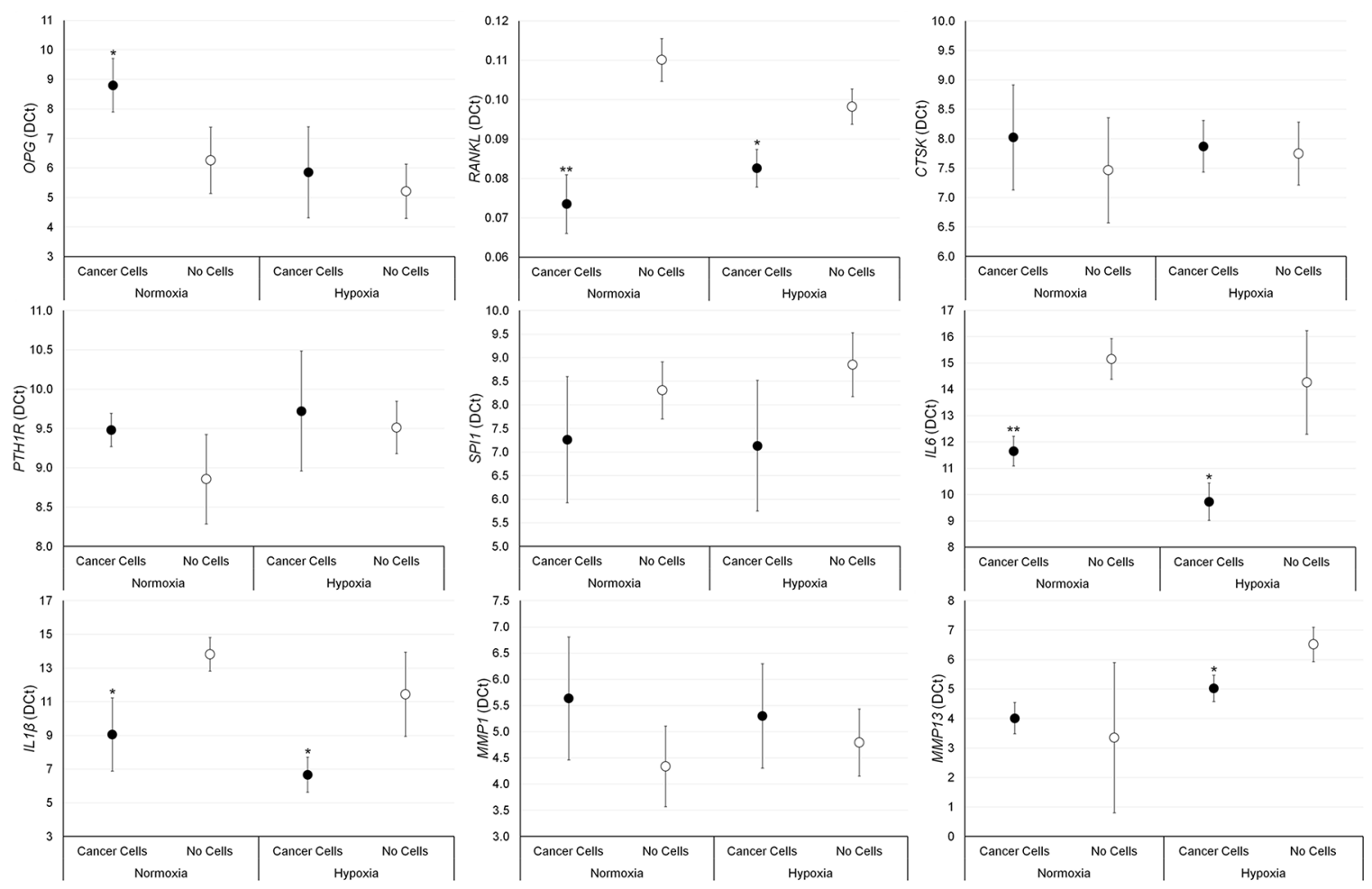

Figure 6: Gene expression analysis ( $n=3$ replicates) in male bone fragments cultured with or without PC-3 cancer cells, both in normoxic and hypoxic conditions. RANKL (normoxia: ${ }^{*} p<0.005$; hypoxia: ${ }^{*} p<0.05$ ), IL-6 (normoxia: ${ }^{*} p<0.005$; hypoxia: ${ }^{*} p<0.05$ ), IL-1 $\beta$ and (normoxia and hypoxia: ${ }^{*} p<0.05$ ) MMP-13 (hypoxia* $p<0.05$ ): bone fragments with PC-3 versus bone fragments without cancer cells. OPG (normoxia and hypoxia: ${ }^{*} p<0.05$ ): bone fragments without cancer cells versus bone fragments with PC-3. 
increases the growth of metastatic tumor cells that have adapted for survival in conditions of low $\mathrm{O}_{2}$.

We studied cancer/cell bone interaction over a relatively long period of up to 7 days. Unlike other reports $[18,25]$ we did not observe a decline in bone marrow viability after 7 days (T1) of culture as revealed by the Alamar Blue test and appearance in histological sections. In fact, the bone viability results obtained immediately after surgery (T0) were maintained after 7 days (T1) of culture with and without cancer cells (MCF-7 and PC-3), in both normoxic and hypoxic conditions.
Co-culture of human bone fragments with human breast or prostate cancer cells in suspension were evaluated for protein expression level and for gene expression profile. Co-culture of bone with MCF-7 cells, both in hypoxic and in normoxic conditions, resulted in increased transcription of genes associated with osteoclasts division, differentiation, and activation, such as RANKL, CTSK, PTH1R, IL-6 and IL- $1 \beta$ while there was a repression of OPG, which is associated with osteoblasts maturation [27-30]. The up-regulation of RANKL, IL-1 $\beta$ but also TNF- $\alpha$ and the down-regulation of OPG have
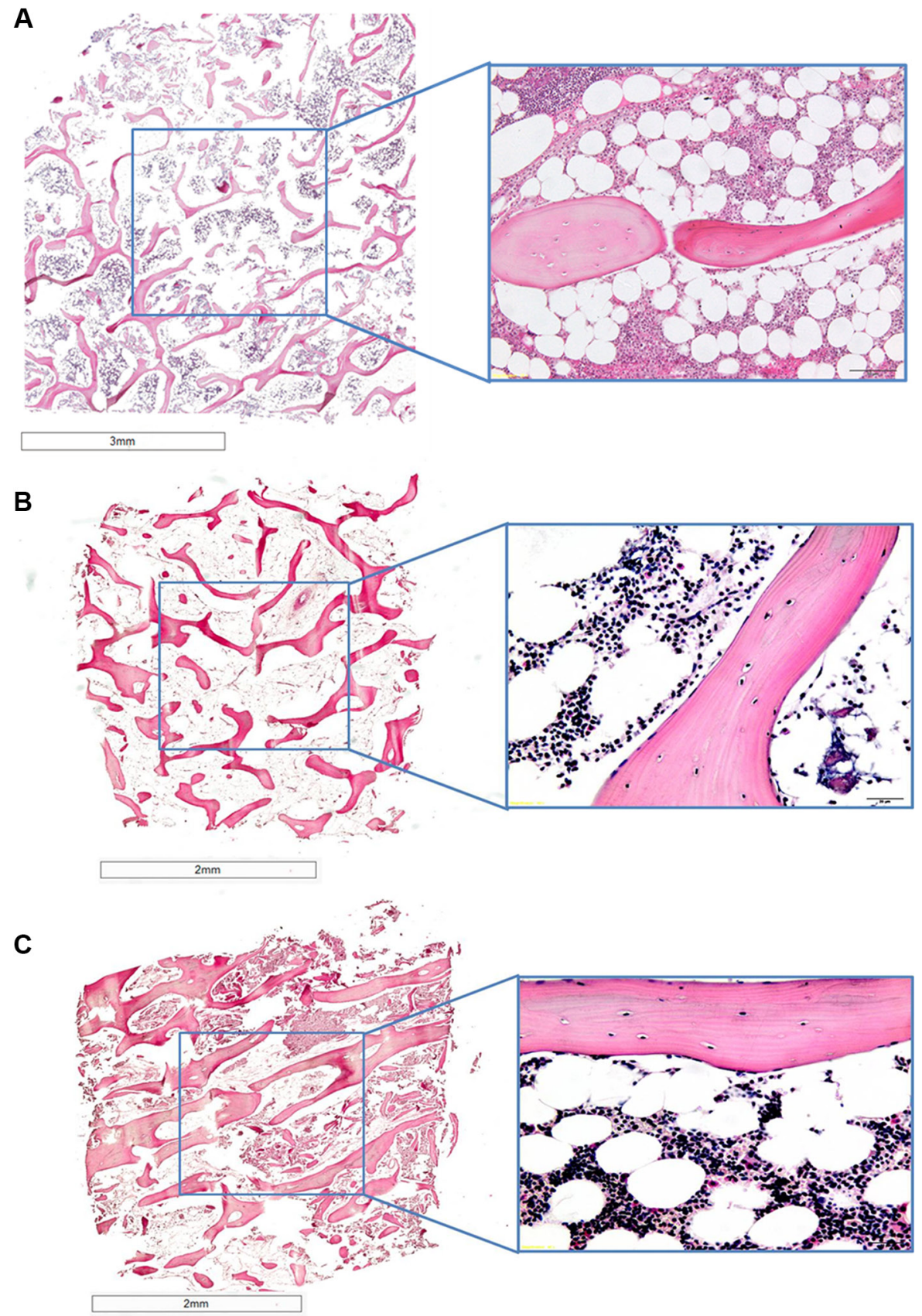

Figure 7: H/ E stained sections of human bones grown in the absence of cancer cells at (A) T0 and (B) and (C) at T1, (B) in normoxic conditions and (C) hypoxic conditions. $1.25 \times$ and $40 \times$ of magnification. 


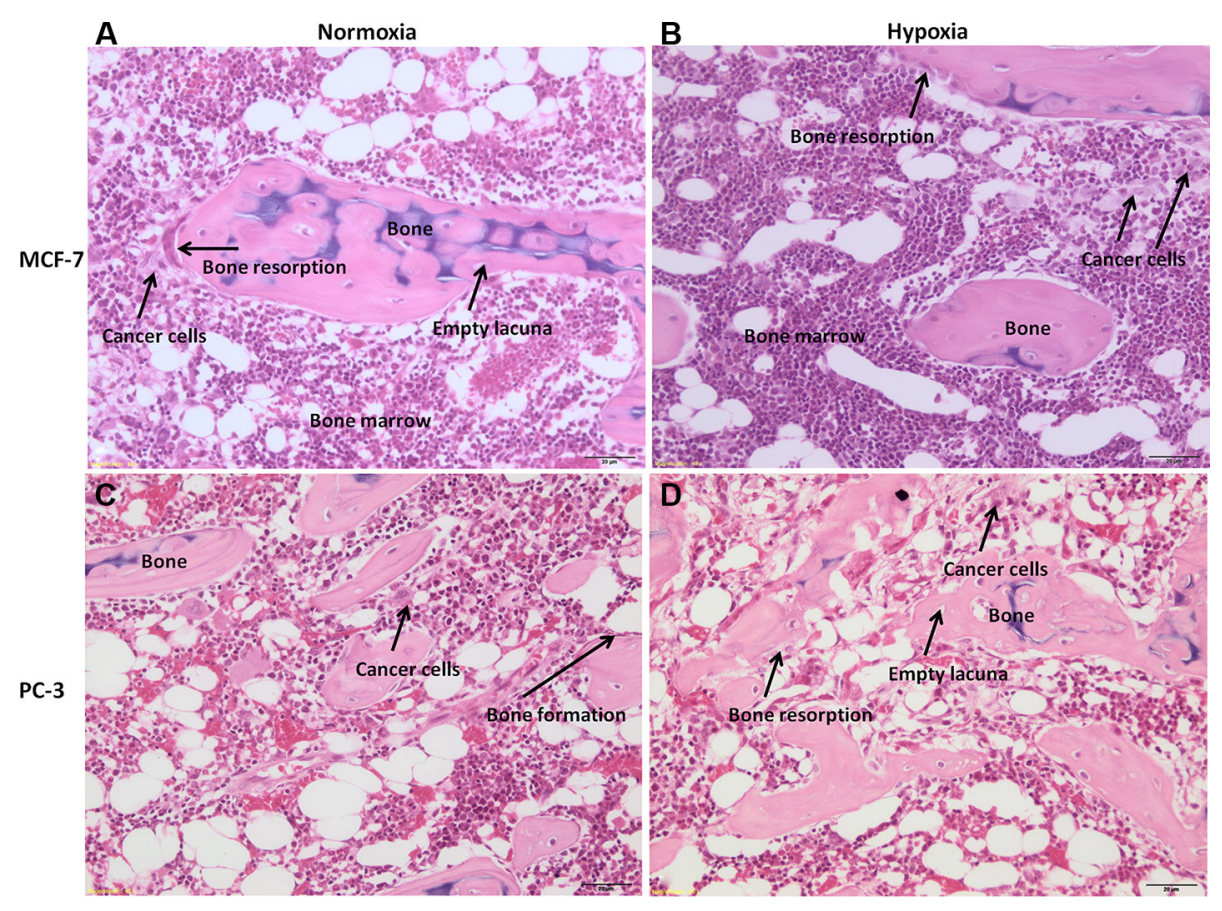

Figure 8: H/ E stained sections of human bone femoral head specimens grown in the presence of human cancer cells, both MCF-7 or PC-3, under normoxic and hypoxic conditions. (A and B) Human bone from females patients cultured in the presence of MCF-7 breast cancer cell lines under (A) normoxic and (B) hypoxic conditions. (C and D) Human bone from males patients cultured in the presence of PC-3 prostate cancer cell lines under (C) normoxic and (D) hypoxic conditions. All sections are at 40× magnification.

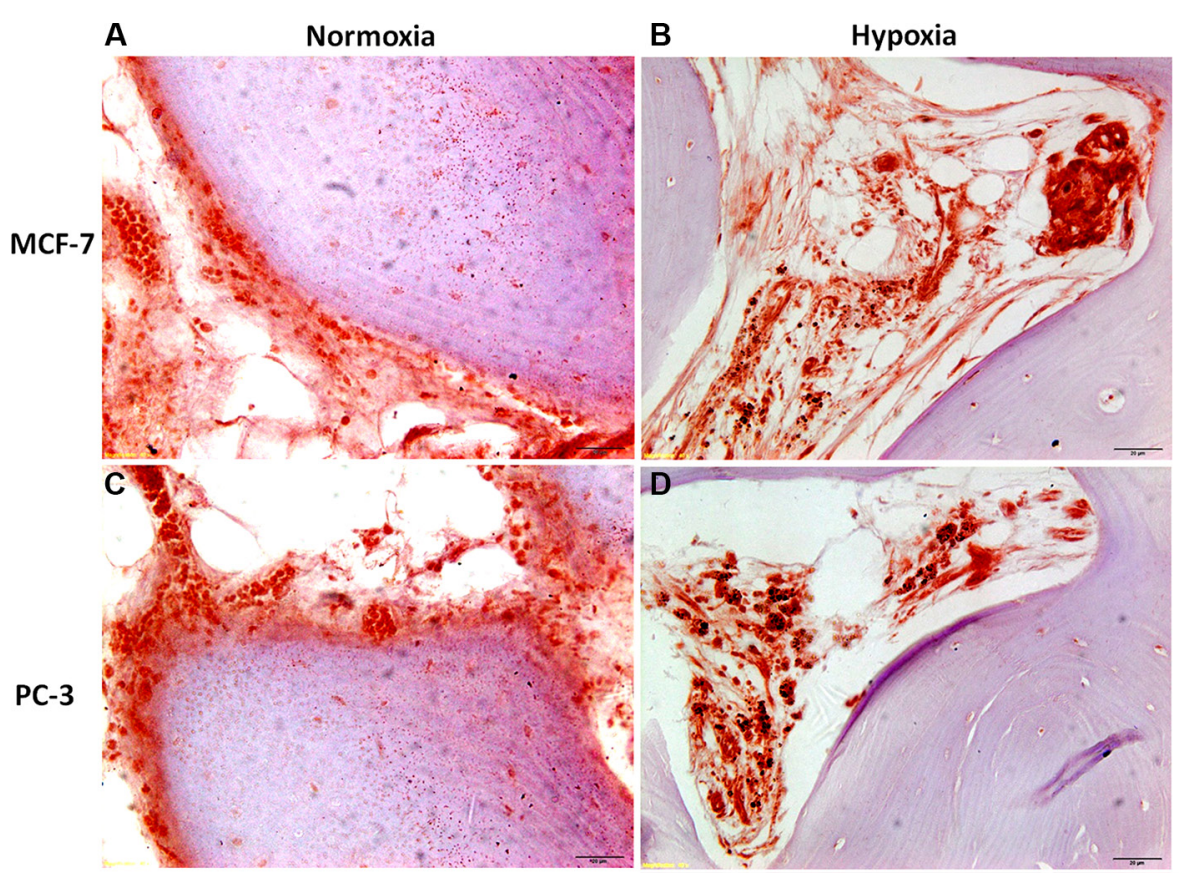

Figure 9: Immunohistochemical staining of femoral head bone specimens after co-culture with (A and B) MCF-7 and (C and D) PC-3 cells for 7 days with cytokeratin 18 antibody reveals (A) and (B) MCF-7 breast cancer cell and (C) and (D) prostate cancer cell colonization (in red) of the bone marrow compartment and attachment to ossified bone surface. All sections are at $80 \times$ magnification 
also been observed at protein expression level. This increased transcription of genes and protein expression, associated with the activation and function of osteoclasts, was further emphasized under hypoxic condition where an increased transcriptional activity of SPI1, a gene involved in a transcriptional regulatory network typically associated with osteoclastogenesis, was observed [31-33]. In addition to destructive bone loss and related clinical complications, tumor-induced osteoclasts contribute also to the establishment, growth, and survival of tumors. In fact, products of osteoclastic bone resorption increase tumor cell proliferation and survival and cause further production of osteolytic and osteoblastic factors, thereby creating a positive feedback loop known as the "vicious cycle". As osteoclasts are highly related to macrophages, it is well known that many pro-tumorigenic factors can be produced by osteoclasts directly, including IL-1, TNF and IL-6, in addition to matrix metalloproteinases [34-35]. MMPs are also important mediators of bone resorption, yet only have the capacity to breakdown proteins in nonmineralized bone [27]. The main MMPs associated with bone resorption are MMP-1, MMP-9, and MMP-13; all of which are collagenases [36]. High levels of MMPs have also been related to the metastatic characteristics of a number of tumors, and in our model we found an increased transcriptional activity of MMP-1 and MMP-13, the latter only in hypoxic environment. These data closely reflects the osteolytic characteristic of MCF-7 breast cancer cells and therefore this model has also the ability to correlate the specific metastatic potential of this cells on bone, in particular under hypoxic conditions. In fact, hypoxia stimulates blood cell proliferation and blood vessel formation, and modulates the expression of extracellular matrix components and remodeling enzymes, thereby maintaining tissue homeostasis. In contrast to the strong osteolytic effects on human bone fragments co-cultured with MCF-7 cells, when PC-3 prostate cancer cells were co-cultured with human bone we were able to show that there was an initial subtle mixed effect (i.e., osteolytic and osteoblastic). Co-culture of bone with PC-3 cells, both in hypoxic and in normoxic conditions, resulted in increased transcription of RANKL, IL- 6 and IL- $1 \beta$ genes and in a repression of OPG gene expression. However, no differences were seen concerning CTSK, PTH1R and SPI1 expression that are key genes in the transcriptional regulatory network of osteoclastogenesis. In addition, different results were obtained for protein expression level where no significant change in RANKL expression and higher levels of OPG, only in normoxic condition, were found. We hypothesized that this different gene and protein expression was associated to the fact that OPG may play an autoregulatory role during osteoclastogenesis in an intrinsic mechanism that negatively regulate its expression. A negative feedback in osteoclastogenesis was already reported by Kang et al. [37] who suggested that OPG, expressed by the osteoclasts themselves, may play an auto-regulatory role during osteoclastogenesis through the induction of apoptosis. However, despite our hypothesis

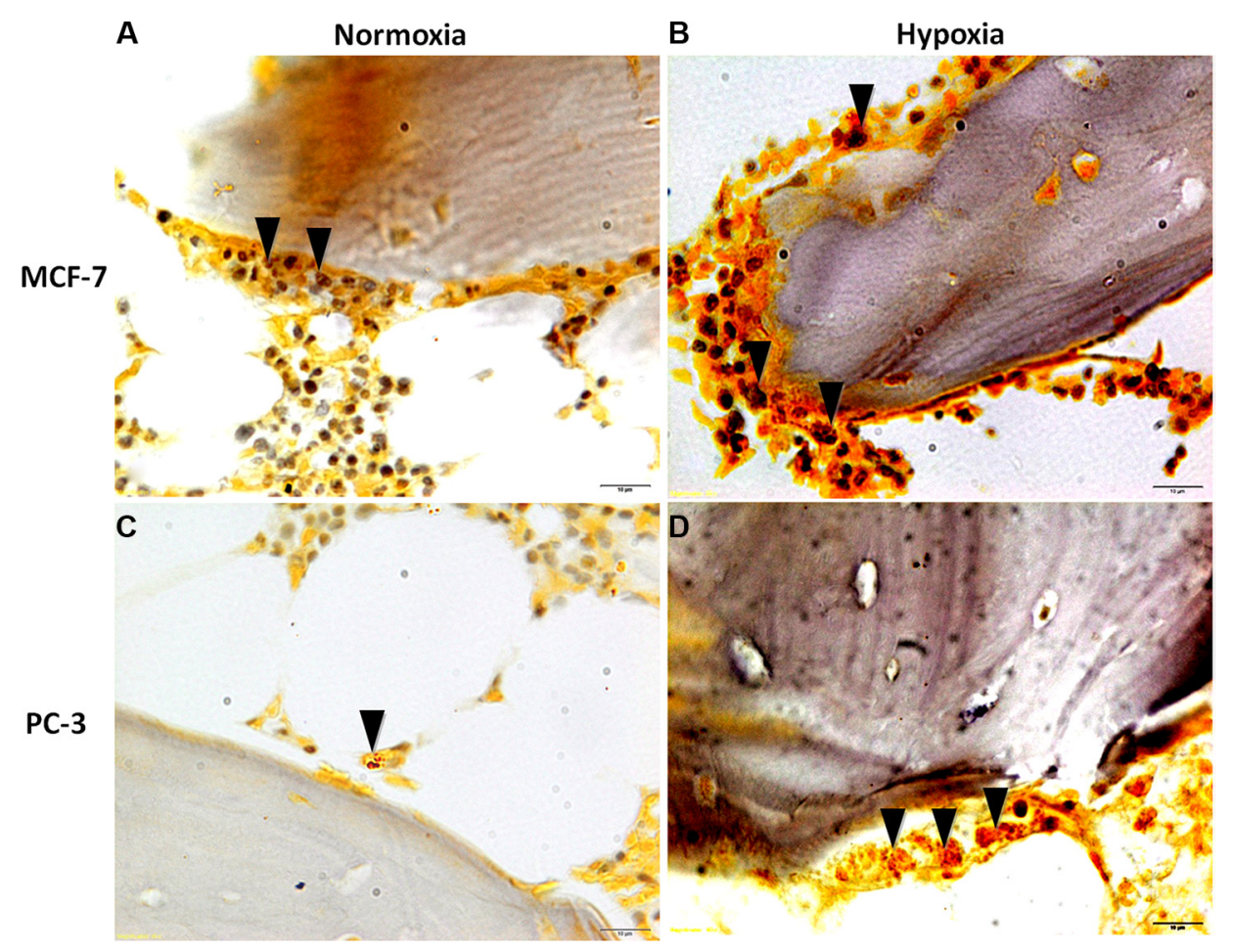

Figure 10: TRAP staining of femoral head bone specimens after co-culture with (A and B) MCF-7 and (C and D) PC-3 cells for 7 days. Presence of differentiated multinucleated osteoclasts throughout the trabecular bone (black arrows). All sections are at $80 \times$ magnification. 
on the possible autoregulatory role of OPG during osteoclastogenesis, this study underlined the presence of still numerous doubts regarding the serious question of how the OPG/RANKL/RANK or OPG/TRAIL/death receptor system interacts during osteoclastogenesis. Finally, it should be carefully noted that the correlation between gene expression and protein levels has always been a very intriguing issue. Interpreting protein levels based on mRNA expression may be misleading. In our experience, protein levels do not necessarily reflect gene expression levels. In fact, change in mRNA levels and protein levels may not correlate well mainly due to the regulation control at different levels, i.e transcriptional regulation and post-transcriptional regulation (RNA processing, RNA stability, translational, protein stability and protein modification). Concerning TNF- $\alpha$, that enhances osteoclasts function leading to bone degradation, its up-regulation, also observed at the protein expression level. Finally, also an increase in the transcriptional activity of MMP-13, only under hypoxic condition, was observed when PC-3 cells were present. MMP-13 is an important mediator of cell-tumor communications by processing soluble factors, such as RANKL, which in turn stimulate osteoclastogenesis [27]. In addition, MMP-13 is implicated in the enzymatic cascade because proMMP-13 is activated by MMP-2 and by MMP-14, which can also turn on proMMP-2. Once active, both MMP-2 and MMP-13 take part in the activation of proMMP-9 into MMP-9. In this way, MMP-13 is implicated both in metastatic and non-metastatic tumors, where molecular expression is spurred by numerous cytokines, growth factors and tumor promoters that act on tumor cells.

Results of protein expression level and of gene expression profile were confirmed also by histology; co-culture with human breast or prostate cancer cells in suspension with free-floating human bone fragments caused local trabecular bone architectural alteration. In addition, marked cancer cell penetration with characteristic foci of neoplastic cells, with two or more hyperchromatic nuclei for cell, was observed in bone fragments cultured both with breast or prostatic cancer cells. MCF-7 and PC-3 cells migrated towards the femoral head bone specimens and also into the bone marrow spaces. The results also denoted different degrees of bone resorption areas between the different cancer cell types (MCF-7 or PC-3). In fact, bone metastases from MCF-7 cancer cells were nearly always associated with osteolysis, whereas bone metastases from PC-3 cancer cells were prevalently mixed (i.e., osteolytic and osteoblastic) [22]. Thus, our model reflects closely the osteolytic and the osteolytic/ osteoblastic (mixed type) characteristics of the cancer cell lines used and hence the model also has the ability to correlate the specific metastatic potential of these cells on bone. Cancer cell colonization of bone tissue was also confirmed with immunohistochemical analyses, which revealed cytokeratin positive breast and prostate cancer cells within the marrow and ossified compartments. In hypoxic conditions both MCF-7 and PC-3 colonized mainly the bone marrow compartment. This is probably due to the bone marrow environment, which in hypoxic conditions is more susceptible to the invasion and growth of tumor cells [38-39]. Additionally, a greater amount of multinucleated osteoclasts were observed in the hypoxic condition with respect to that of the normoxic one. The ability of the cancer cells to promote the formation of active osteoclasts is a special property of tumors which metastasize to bone, and a necessary requirement to initiate and sustain tumor expansion. Sabino et al. [40] showed that under hypoxic conditions tumor cells produce prostaglandin E2 (PGE2) at increased levels. PGE2 is synthesized in bone principally by osteoblasts to stimulate bone resorption and is regulated by cyclo-oxygenase (COX) enzymes. Miyaura et al [41] observed that in cancer metastases and bone resorption PGE2 binds to the EP4 receptor (a PGE receptor subtype) to induce RANKL expression and stimulation of bone destruction.

This model was also evaluated by a 4D computational methodology by micro-CT to track the presence of changes in bone volume fraction, BMD and TMD in a non-invasive simultaneous manner as a result of the presence of cancer cells. This 4D approach has several strengths, as it allows, besides achieving 3D measures similar to traditional 2D histology, for a temporal characterization of the occurring bone (re)modeling sequences. Thus, this computational methodology provides several new ways to examine bone turnover, including the temporal character of formation and resorption processes and (re)modeling sequences both in healthy and pathological conditions. In this application, after recording micro-CT datasets of the femoral head bone fragments at T0 without cells and at T1 after 7 days of culture with cancer cells, the 2 volumes were superimposed, thus allowing the measurement of bone remodeling and mineral density over time. After 7 days of culture, no significant differences were found among bone specimens both in hypoxic and in normoxic conditions. However, in normoxic condition we found that BMD values increased in bone cultured with MCF-7 and decreased in PC-3 cultured bone. Moreover, in hypoxic conditions TMD decreased in bone femoral head specimens cultured with both cancer cells in comparison to the same specimens at T0 in hypoxic conditions. These result highlighted how hypoxia can promote a more physiological environment, which leads to bone resorption in breast cancer metastases, and it induces more bone resorption that bone formation in prostate cancer metastases. The lower BMD and TMD found in this study indicated a decrease in bone mineral content that is the primary recognizable cause of bone loss and subsequent osteolysis [42]. Bone density measurement is thought to be the most reliable and reproducible method for assessment and quantification of bone metastases in different anatomical districts [43]. 
Promising results were thus obtained from this $3 \mathrm{D}$ model; however some limitations of the study and a future possible upgrade should be considered by using a larger sample. Firstly, we followed cell/bone interaction up to 7 days, thus an essential improvement would be to optimize culture conditions for longer experimental times also in order to study microstructural and density bone parameters. Secondly, further exploration of any molecular change should be performed in order to identify other key pathways and factors that might contribute to bone metastases. Finally, the lack of a functioning circulatory system in this model prevents the study of cancer cell extravasation.

In conclusion, this dynamic 3D system supports the "proof of concept" for the application of this model for the recapitulation of in vivo cancer-bone metastasis spread, in particular monitoring and controlling hypoxia that seems to better mimic physiological tumors condition. Moreover, the model might serve as an efficient system at a higher level than the $2 \mathrm{D}$ cell culture model, but at a lower ethical cost. The proposed system, in comparison to other models, seems to be cost effective and consequently a greater amount of experiments might be performed to obtain extensive datasets for reliability, reproducibility and statistical analysis.

The versatility of this $3 \mathrm{D}$ model offers the possibility to further explore the application of the model for other clinical applications, e.g. increasing the biological complexity of the system by adding other cell types or increasing the culture time. This will ultimately benefit the development of new therapies and improve disease management. In fact, in the future, we plan to use this model also for characterizing other metastatic cancer cells from patients, thus highlighting the physiological events that occur when cancer cells encounter the bone. All these aspects will greatly enrich the existing knowledge on the bone metastasis by providing a specific link to the clinical situation, thus making this 3D model an attractive tool for multidisciplinary experts, namely clinicians, biologists and bioengineers.

\section{MATERIALS AND METHODS}

\section{Human bone tissue cultures}

The study was approved by the Ethics Committee of the Rizzoli Orthopedic Institute (Protocol MET-3D; approved May 22, 2014) and informed consent was obtained from all subjects. The main clinical characteristics of the patients are listed in Table 1. Exclusion criteria were human immunodeficiency virus (HIV), hepatitis B virus (HBV), hepatitis C virus (HCV), pregnancy, osteoporosis, primary bone tumors and bone metastases, minors and/or patients incapable of giving consent personally.

Femoral heads were collected from twelve patients, 6 female and 6 male undergoing total hip replacement at Rizzoli Orthopedic Institute. Briefly, with the patient in supine position a minimally invasive direct lateral approach was performed. After anterior capsulotomy the hip was dislocated anteriorly and a femoral neck osteotomy was performed approximately one $\mathrm{cm}$ proximally to the lesser trochanter. Subsequently, at a distance of about $3 \mathrm{~cm}$ from the articular cartilage, a $1-\mathrm{cm}$ thick section of the same width as the femur was cut with a surgical saw. From this section we obtained 16 bone specimens per patient with height and length equal to $1.0 \pm 0.3 \mathrm{~cm}$ and weighing between 0.8 and $1.0 \mathrm{~g}$. Bone specimens were placed singularly in a $15 \mathrm{ml}$ TubeSpin Bioreactor, where the gas exchange is ensured by a screw cap with a $0.22 \mu \mathrm{m}$ filter membrane (TPP TubeSpin ${ }^{\circledR}$ Bioreactors, TPP Techno Plastic Products, Switzerland), containing $3 \mathrm{ml}$ of culture medium. The live organ culture medium consisted of Dulbecco's Modified Eagle's Medium (DMEM, Sigma-Aldrich, MO, USA) supplemented with $5 \mathrm{mg} / \mathrm{ml}$ of bovine serum albumine (BSA, SigmaAldrich, MO, USA), $2 \mathrm{mM}$ glutamine and antibiotics (100 U/ml penicillin, $100 \mu \mathrm{g} / \mathrm{ml}$ streptomycin) (Gibco, INVITROGEN Corporation, Carlsbad, CA) and with no fetal calf serum. The bone specimens in the TubeSpin Bioreactor, were transported to the laboratory within 20 minutes after surgery and twelve of them were immediately placed in a rolling apparatus (Thermo Scientific, Waltham, MA, USA) with a $20^{\circ}$ inclined plane at 5 revolutions per minute for 24 hours at $37^{\circ} \mathrm{C}$ in a humidified $5 \% \mathrm{CO}_{2}$ incubator (Thermo Scientific, Waltham, MA, USA) (Figure 11A). Two specimens were used as positive controls and immediately evaluated for viability by the alamar blue test. The remaining two bone specimens were used as negative controls, they were soaked for five times in liquid nitrogen $\left(-196^{\circ} \mathrm{C}\right)$ for $4 \mathrm{~min}$ and then incubated $\left(37^{\circ} \mathrm{C}\right)$ for $4 \mathrm{~min}$ to induce total necrosis of the trabeculae and bone marrow depletion.

\section{Cells lines and cell culture}

The human breast adenocarcinoma MCF-7 cell line was cultured using DMEM medium (Sigma-Aldrich, MO, USA) whereas the human prostate cancer PC-3 cell line was cultured in RPMI 1640 (GIBCO, Invitrogen, Life Technologies, $\mathrm{CA}, \mathrm{USA}$ ) at $37^{\circ} \mathrm{C}$ in a humidified $5 \% \mathrm{CO}_{2}$ incubator (Hera Cell 150i; Thermo Scientific, Waltham, MA, USA). Mediums contained 10\% FCS (Lonza, Verviers, Belgium) and $2 \mathrm{mM}$ glutamine and antibiotics (100 U/ml penicillin, $100 \mu \mathrm{g} / \mathrm{ml}$ streptomycin) (Gibco, INVITROGEN Corporation, Carlsbad, CA). Cultures were supplemented with fresh medium every two days.

\section{D co-culture system}

After 24 hours at $37^{\circ} \mathrm{C}$ in a humidified $5 \% \mathrm{CO}_{2}$ incubator on a rolling apparatus, $2.5 \times 10^{4}$ cancer cells $/ \mathrm{ml}$ in suspension (MCF-7 in female bone specimens and PC-3 in male bone specimens) were added to six of the twelve 
Table 1: Clinical features of patients undergoing total hip replacement

\begin{tabular}{|c|c|c|c|c|c|c|c|c|c|c|c|c|}
\hline & $\begin{array}{c}\text { Patient } \\
1 .\end{array}$ & $\begin{array}{l}\text { Patient } \\
2 .\end{array}$ & $\begin{array}{c}\text { Patient } \\
3 .\end{array}$ & $\begin{array}{l}\text { Patient } \\
4 .\end{array}$ & $\begin{array}{c}\text { Patient } \\
5 .\end{array}$ & $\begin{array}{c}\text { Patient } \\
6 .\end{array}$ & $\begin{array}{c}\text { Patient } \\
7 .\end{array}$ & $\begin{array}{c}\text { Patient } \\
8 .\end{array}$ & $\begin{array}{c}\text { Patient } \\
9 .\end{array}$ & $\begin{array}{c}\text { Patient } \\
10 .\end{array}$ & $\begin{array}{l}\text { Patient } \\
11 .\end{array}$ & $\begin{array}{l}\text { Patient. } \\
12\end{array}$ \\
\hline Gender & Female & Female & Female & Female & Female & Female & Male & Male & Male & Male & Male & Male \\
\hline Age & 60 & 68 & 58 & 60 & 75 & 61 & 79 & 82 & 60 & 61 & 58 & 73 \\
\hline Height (cm) & $155 \mathrm{~cm}$ & $158 \mathrm{~cm}$ & $153 \mathrm{~cm}$ & $162 \mathrm{~cm}$ & $157 \mathrm{~cm}$ & $146 \mathrm{~cm}$ & $160 \mathrm{~cm}$ & $160 \mathrm{~cm}$ & $181 \mathrm{~cm}$ & $170 \mathrm{~cm}$ & $157 \mathrm{~cm}$ & $175 \mathrm{~cm}$ \\
\hline Weight (Kg) & $75 \mathrm{Kg}$ & $85 \mathrm{Kg}$ & $60 \mathrm{Kg}$ & $60 \mathrm{~kg}$ & $58 \mathrm{Kg}$ & $71 \mathrm{Kg}$ & $72 \mathrm{~kg}$ & $58 \mathrm{Kg}$ & $84 \mathrm{Kg}$ & $82 \mathrm{Kg}$ & $84 \mathrm{Kg}$ & $60 \mathrm{Kg}$ \\
\hline BMI & $\begin{array}{l}31.22 \\
\mathrm{Kg} / \mathrm{m}^{2}\end{array}$ & $\begin{array}{l}34.05 \\
\mathrm{Kg} / \mathrm{m}^{2}\end{array}$ & $\begin{array}{l}25.63 \\
\mathrm{Kg} / \mathrm{m}^{2}\end{array}$ & $\begin{array}{c}22.9 \\
\mathrm{Kg} / \mathrm{m}^{2}\end{array}$ & $\begin{array}{c}23.5 \\
\mathrm{Kg} / \mathrm{m}^{2}\end{array}$ & $\begin{array}{c}33.8 \\
\mathrm{Kg} / \mathrm{m}^{2}\end{array}$ & $\begin{array}{l}28.12 \\
\mathrm{Kg} / \mathrm{m}^{2}\end{array}$ & $\begin{array}{l}22.66 \\
\mathrm{Kg} / \mathrm{m}^{2}\end{array}$ & $\begin{array}{l}25.64 \\
\mathrm{Kg} / \mathrm{m}^{2}\end{array}$ & $\begin{array}{l}28.40 \\
\mathrm{Kg} / \mathrm{m}^{2}\end{array}$ & $\begin{array}{l}34.10 \\
\mathrm{Kg} / \mathrm{m}^{2}\end{array}$ & $\begin{array}{c}19.00 \\
\mathrm{Kg} / \mathrm{m}^{2}\end{array}$ \\
\hline BMD & $\geq-1.0$ & $\geq-1.0$ & $\geq-1.0$ & $\geq-1.0$ & $\geq-1.0$ & $\geq-1.0$ & $\geq-1.0$ & $\geq-1.0$ & $\geq-1.0$ & $\geq-1.0$ & $\geq-1.0$ & $\geq-1.0$ \\
\hline Comorbidities & No & $\begin{array}{l}\text { Hypertension, } \\
\text { hypothyroidism, } \\
\text { depression, } \\
\text { gastritis, } \\
\text { ischemic } \\
\text { heart disease. }\end{array}$ & No & $\begin{array}{l}\text { Depression, } \\
\text { heart } \\
\text { disease. }\end{array}$ & Depression. & Hypertension & No & $\begin{array}{l}\text { Prostatic } \\
\text { hypertrophy, } \\
\text { chronic } \\
\text { obstructive } \\
\text { pulmonary } \\
\text { disease, heart } \\
\text { disease. }\end{array}$ & Hypertension & No & $\begin{array}{l}\text { Hypertension, } \\
\text { hypercholeste } \\
\text { rolemia }\end{array}$ & $\begin{array}{c}\text { Hypertension, } \\
\text { diabetes }\end{array}$ \\
\hline $\begin{array}{l}\text { Use of drugs } \\
\text { active on bone } \\
\text { metabolism }\end{array}$ & No & No & No & No & No & No & No & No & No & No & No & No \\
\hline
\end{tabular}

bone specimens cultured in the TubeSpin Bioreactor. Three of them were cultured for a further 7 days in a rolling apparatus with a $20^{\circ}$ inclined plane at 5 revolutions per min at $37^{\circ} \mathrm{C}$ in hypoxic conditions in a humidified $2 \% \mathrm{O}_{2}, 5 \% \mathrm{CO}_{2}$ and $88 \% \mathrm{~N}_{2}$ incubator (Hera Cell 150i; Thermo Scientific, Waltham, MA, USA), whereas the other three tubes were cultured in normoxic conditions: in a humidified 5\% $\mathrm{CO}$ incubator (Hera Cell 150i; Thermo Scientific, Waltham, MA, USA) (Figure 11A and 11B). The remaining six bone specimens were cultured without cancer cells, both in hypoxic $(n=3)$ and in normoxic $(n=3)$ conditions.

After 7 days of culture bone specimens from 6 patients, 3 female and 3 male, were immediately processed
A

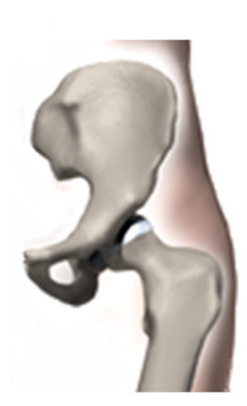

3D model set-up

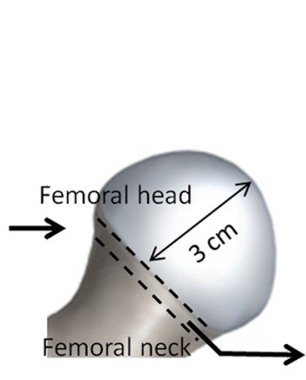

$1 \mathrm{~cm}$ thick section

\section{model set-up}
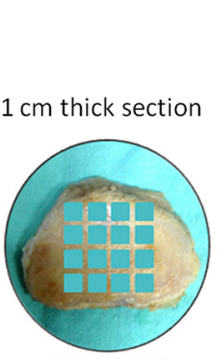

TubeSpin Bioreactor

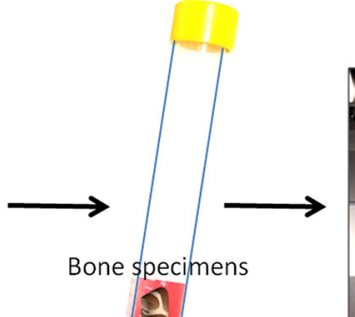

Rolling apparatus, $20^{\circ}$

inclined plane, 5 revolution per $\min , 37^{\circ} \mathrm{C}$ in a humidified $5 \% \mathrm{CO}_{2}$ incubator
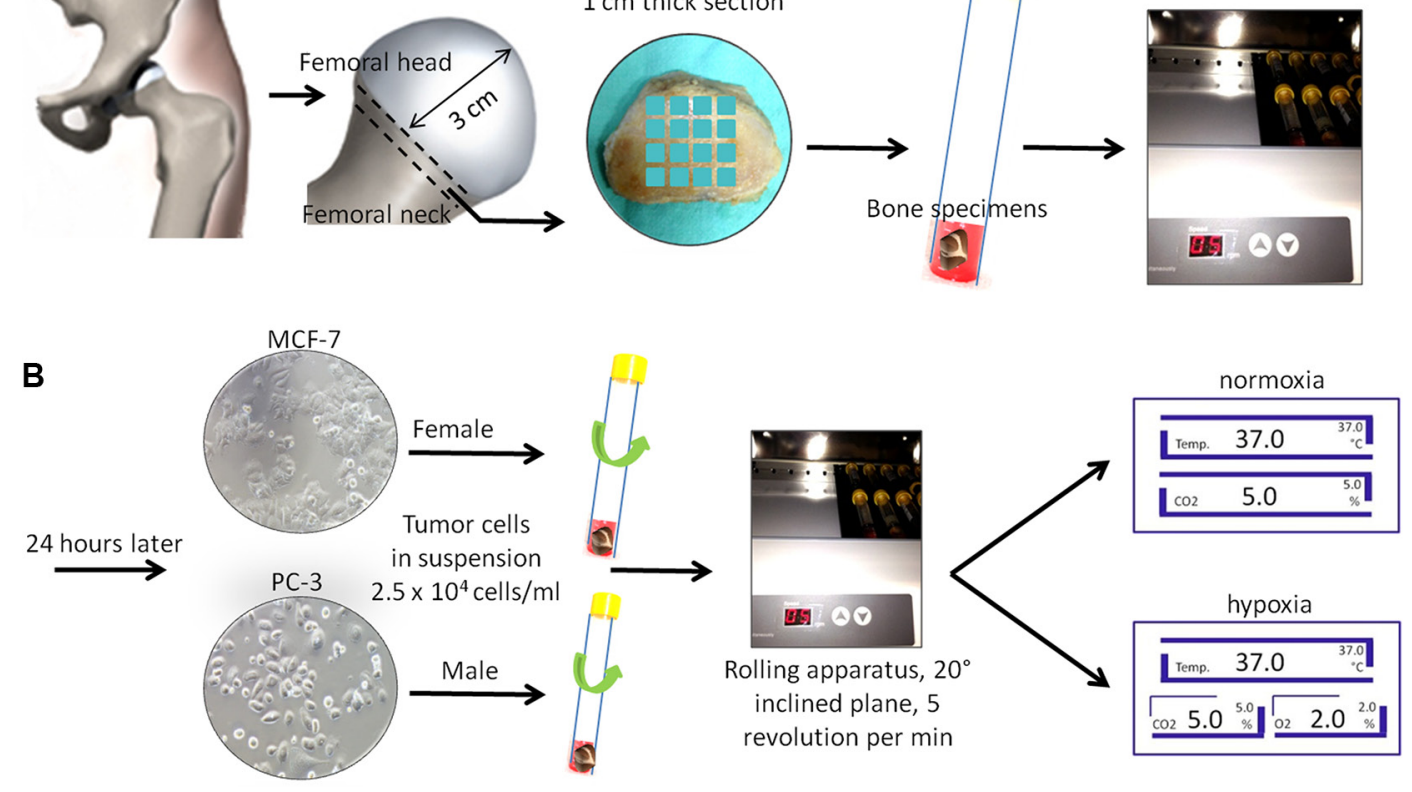

Figure 11: Schematic representation of the 3D model set-up. (A) Femoral head and neck resection and cut of 1-cm thick section. Bone femoral samples $(1 \times 1 \mathrm{~cm})$ were placed in a TubeSpin Bioreactor and with a $20^{\circ}$ inclined plane in a rolling apparatus at 5 revolutions per minute for 24 hours at $37^{\circ} \mathrm{C}$ in a humidified $5 \% \mathrm{CO}_{2}$ incubator. (B) After 24 hours $2.5 \times 10^{4} \mathrm{cells} / \mathrm{ml}$ in suspension (MCF-7 in female bone specimens and PC-3 in male bone specimens) were added. Rolling TubeSpin were cultured for 7 days in a rolling tube apparatus $\left(20^{\circ}\right.$ inclined plane and 5 revolutions $/ \mathrm{min}$ ) at $37^{\circ} \mathrm{C}$ in hypoxic conditions: in a humidified $2 \% \mathrm{O}_{2}, 5 \% \mathrm{CO}_{2}$ and $88 \% \mathrm{~N}_{2}$ incubator or in normoxic conditions: in a humidified $5 \% \mathrm{CO}_{2}$ incubator. 
for bone viability, densitometric and structural evaluations by micro-CT analyses and successively fixed as described above for histological and immunohistochemical analyses. Bone specimens from the remaining 6 patients, 3 female and 3 male, were used for gene expression analyses. Media were collected, centrifuged and stored at $-20^{\circ} \mathrm{C}$ for ELISA protein assays.

Finally, six TubeSpin Bioreactor tubes with breast cancer cells alone, MCF-7, and 6 for prostate cancer cells, PC-3, $\left(2.5 \times 10^{4}\right.$ cells $\left./ \mathrm{ml}\right)$ were incubated at $37^{\circ} \mathrm{C}$ for 7 days on the rolling apparatus $\left(20^{\circ}\right.$ inclined plane and 5 revolution/min) in hypoxic and in normoxic conditions.

The summary of the experimental set up is shown in Table 2.

\section{ELISA protein assay}

Supernatants from each culture condition were collected and centrifuged to remove particulates. Aliquots were dispensed in Eppendorf tubes for storage at $-20^{\circ} \mathrm{C}$ and assayed for osteoprotegerin (OPG), Receptor Activator for Nuclear factor KB Ligand (RANKL), interleukin $1 \beta$ (IL-1 $\beta$ ), and tumor necrosis factor $\alpha(\mathrm{TNF}-\alpha)$ (Boster Biological Technology Co. Ltd, Wuhan, China). The concentration of each factor (OPG, RANKL, IL-1 $\beta$ and TNF- $\alpha$ ) was normalized by the weight of the bone fragment.

\section{Bone tissue viability}

The alamar blue test (Serotec, Oxford, UK) was used to evaluate viability of bone at time 0 (T0) (both in positive controls and in negative controls) and after 7 days of culture (T1). The reagent is a dye, which incorporates an oxidation-reduction (REDOX) indicator that changes color in response to the chemical reduction of growth medium, resulting from cell growth. It was added to each bone specimen $(1: 10 \mathrm{v} / \mathrm{v})$ for $4 \mathrm{~h}$ at $37^{\circ} \mathrm{C}$. After transferring the supernatants to 96 -well plates, the absorbance of supernatant was read spectrophotometrically at 570 and $600 \mathrm{~nm}$ wavelengths (for the fully oxidized and reduced forms of reagent) by a microplate reader (BioRad, CA, USA). The results, obtained as optical density (OD) data, were processed following the manufacturer's instructions and expressed as reduction percentage.

\section{D micro-CT analyses}

After bone viability assessment femoral head bone specimens were scanned both at the beginning and at the end of the 7 days' cell culture using the Skyscan 1172 micro-CT system (Bruker microCT, Kontich, Belgium). The specimens were scanned in their culture medium at $70 \mathrm{kV}$ of source voltage and $140 \mu \mathrm{A}$, with a total rotation of $180^{\circ}$ and a rotation step of $0.4^{\circ}$. An aluminum filter of $0.5 \mathrm{~mm}$ was used between the source and the sample. The image pixel size was $12 \mu \mathrm{m}$ and the scan duration was nearly 45 minutes for every specimen (software Skyscan 1172 version 1.5 build 14, Bruker microCT, Kontich, Belgium). The reconstructions were performed using the software NRecon (version 1.6.9.16, Bruker micro-CT, Kontich, Belgium) and the resulting jpg images had a resolution of $2000 \times 2000$ pixels with a pixel size of $12 \mu \mathrm{m}$. Beam hardening, ring artifacts and the specific misalignment corrections were used. The datasets of the samples before cell culture (reference dataset) and after 7 days (target dataset) were co-registered using an intensity-based method in Dataviewer software (Bruker microCT, Kontich, Belgium). More specifically, rigid transformation $(\mathrm{x} / \mathrm{y} / \mathrm{z}$ translations and $3 \mathrm{D}$ rotations) and matching criteria based on sum of square difference were used. To overcome the problem of mismatching error, due to the presence of debris at the outer bulk surface of the specimens, a Volume of interest (VOI) was considered consisting of a 3D erosion of $0.5 \mathrm{~mm}$ of the bulk specimen volume. To evaluate the bone remodeling occurring as a result of tumor cell/bone cell interaction in our in vitro model at the different conditions, resorbed bone was defined as all bone voxels that were present at $\mathrm{T} 0$ but absent at $\mathrm{T} 1$, whereas formed bone was defined as bone voxels that were present at T1 but absent at $\mathrm{T} 0$. This resulted in a map that indicated the spatial locations of bone formation and resorption sites (Figure 12). The resulting map of bone formation and resorption was then used to obtain the Bone Volume Fraction (BV/TV \%) parameter, expressed as the ratio between the volume of bone within VOI and the total volume of the VOI was evaluated. Moreover, Bone Mineral Density (BMD), inclusive porosity, and Tissue Mineral Density (TMD), exclusive porosity, were also calculated through calibration by two cylindrical phantoms with known concentrations of the mineral compound calcium hydroxyapatite (CaHA). The phantoms, with a diameter similar to that of the specimen (specifically $8 \mathrm{~mm}$ ) and concentration of CaHA of 250 and $750 \mathrm{mg} /$ $\mathrm{cm}^{3}$ were scanned with the same setting specification as that of the bone specimens.

\section{Gene expression analyses}

After 7 days of culture, bone specimens were subjected to cryogenic grinding and pulverization, immersed in liquid nitrogen with Freezer/Mill ${ }^{\circledR} 6770$ $\left(\right.$ SPEX $^{\circledR}$ SamplePrep, Metuchen, NJ, USA), and total RNA extraction was performed by phenol/chlorophorm method withTrizol (Life Technologies, Thermo Scientific, Waltham, MA, USA). RNA was purified on columns with PureLink RNA Mini Kit (Life Technologies, Thermo Scientific, Waltham, MA, USA) according to the manufacturer's instructions. Total RNA was eluted 
Table 2: Summary of the experimental set-up

\section{Experimental set-up}

\begin{tabular}{|l|l|}
\hline Two femoral head specimens & $\begin{array}{l}\text { Immediately evaluated for viability and gene expression } \\
\text { analyses }\end{array}$ \\
\hline Two femoral head specimens & $\begin{array}{l}\text { Immediately used to induce total necrosis of the trabeculae and } \\
\text { bone marrow depletion and evaluated for viability and gene } \\
\text { expression analyses as control }\end{array}$ \\
\hline Three femoral head specimens in the TubeSpin Bioreactors & $\begin{array}{l}\text { Cultured with } 2.5 \times 10^{4} \text { cancer cells/ml for 7 days in normoxic } \\
\text { conditions and evaluated for viability, ELISA protein assay, } \\
\text { densitometric and structural analyses, gene expression analyses } \\
\text { and for histological and immunohistochemical tests }\end{array}$ \\
\hline Three femoral head specimens in the TubeSpin Bioreactors & $\begin{array}{l}\text { Cultured with 2.5 } \times 10^{4} \text { cancer cells/ml for 7 days in hypoxic } \\
\text { conditions and evaluated for viability, ELISA protein assay, } \\
\text { densitometric and structural analyses, gene expression } \\
\text { analyses and for histological and immunohistochemical tests }\end{array}$ \\
\hline Three femoral head specimens in the TubeSpin Bioreactors & $\begin{array}{l}\text { Cultured for 7 days in normoxic conditions and evaluated for } \\
\text { viability, ELISA protein assay, densitometric and structural } \\
\text { analyses, gene expression analyses and for histological and } \\
\text { immunohistochemical tests }\end{array}$ \\
\hline Three femoral head specimens in the TubeSpin Bioreactors & $\begin{array}{l}\text { Cultured for 7 days in hypoxic conditions and evaluated for } \\
\text { viability, ELISA protein assay, densitometric and structural } \\
\text { analyses, gene expression analyses and for histological and } \\
\text { immunohistochemical tests }\end{array}$ \\
\hline $\begin{array}{l}\text { immonales } \\
\text { Bioreactors }\end{array}$ & $\begin{array}{l}\text { Cultured for 7 days in normoxic conditions and evaluated for } \\
\text { viability, ELISA protein assay and gene expression analyses }\end{array}$ \\
\hline $\begin{array}{l}2.5 \times 10^{4} \text { cells/ml of MCF-7 or PC-3 in the TubeSpin } \\
\text { Bioreactors }\end{array}$ & $\begin{array}{l}\text { Cultured for 7 days in hypoxic conditions evaluated for } \\
\text { viability, ELISA protein assay and gene expression analyses }\end{array}$ \\
\hline
\end{tabular}

with RNase-free water, quantified by NanoDrop 2000 (Thermo Scientific, Waltham, MA, USA) and the quality of RNA was evaluated by electrophoresis on $1 \%$ agarose gel. Each RNA sample (500 ng) was reverse transcribed to cDNA using the Super Script VILO cDNA Synthesis kit (Invitrogen, Life Technologies) according to the manufacturer's instructions and diluted to a final concentration of $5 \mathrm{ng} / \mu \mathrm{l}$. Quantification of gene expression for 10 genes (Table 3) was performed in a LightCycler 2.0 Instrument (Roche Diagnostics $\mathrm{GmbH}$, Mannheim, Germany) using QuantiTect SYBR Green PCR kit (Qiagen, Hilden, Germany). Primer details for all genes analyzed are reported in Table 3. Each sample was tested in duplicate. The protocol included:
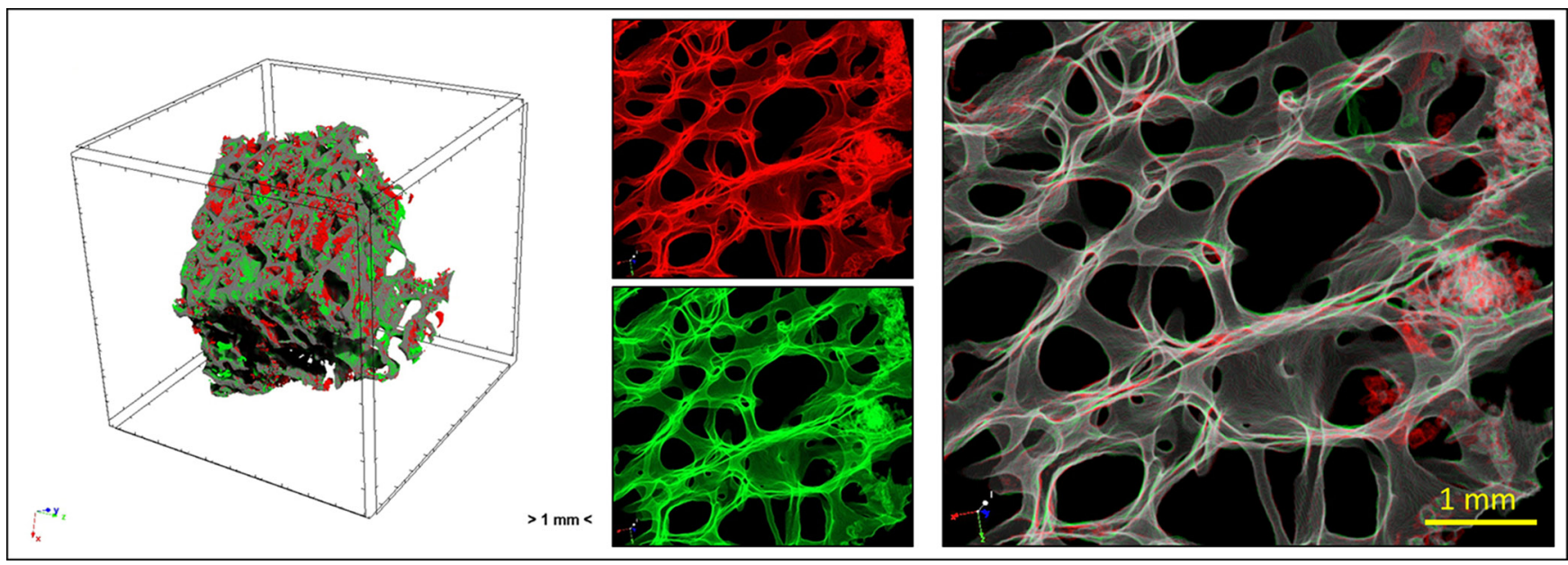

Figure 12: Overview of the study by micro-CT analysis: human femoral head bone specimens were scanned at T0 and T1 and 4D micro-CT analyses was applied to identify regions of bone formation (green) and resorption (red). 
Table 3: Primer details for the analyzed genes

\begin{tabular}{|c|c|c|c|c|c|c|}
\hline Gene & Symbol & Primer Fw (5' $\rightarrow$ 3') & Primer Rv (5' $\rightarrow$ 3') & $T$ annealing & $\begin{array}{l}\text { Amplicon } \\
\text { length }\end{array}$ & Target \\
\hline $\begin{array}{l}\text { Glyceraldehyde- } \\
\text { 3-phosphate } \\
\text { dehydrogenase * }\end{array}$ & GAPDH & TGGTATCGTGGAAGGACTCA & GCAGGGATGATGTTCTGGA & $56^{\circ} \mathrm{C} 20^{\prime \prime}$ & $123 \mathrm{bp}$ & NM_002046 \\
\hline $\begin{array}{l}\text { Tumor Necrosis Factor } \\
\text { (Ligand) Superfamily, } \\
\text { Member } 11 * *\end{array}$ & $\begin{array}{l}\text { TNFSF11 } \\
\text { (RANKL) }\end{array}$ & TGAGATGAGCAAAAGGCTGAG & AGGAGCTGTGCAAAAGGAAT & $60^{\circ} \mathrm{C} 20^{\prime \prime}$ & $134 \mathrm{bp}$ & NM_033012 \\
\hline Osteoprotegerin $* *$ & $\begin{array}{l}\text { TNFRSF11B } \\
(\mathrm{OPG})\end{array}$ & CTACCAAGACACTAAGCCAGT & AAACAGTGAATCAACTCAAAAATGTG & $60^{\circ} \mathrm{C} 20^{\prime \prime}$ & $113 \mathrm{bp}$ & NM_002546 \\
\hline Cathepsin $\mathrm{K}^{* *}$ & CTSK & CAGACAACAGATTTCCATCAGC & СТTCTTCCATAGCTCCCAGTG & $60^{\circ} \mathrm{C} 20^{\prime \prime}$ & $118 \mathrm{bp}$ & NM_000396 \\
\hline $\begin{array}{l}\text { Parathyroid hormone } 1 \\
\text { receptor ** }\end{array}$ & PTHR1 & CTGCACAGCCTCATCTTCA & CTCTGACACTGACCCACAC & $60^{\circ} \mathrm{C} 20^{\prime \prime}$ & $115 \mathrm{bp}$ & NM_000316 \\
\hline $\begin{array}{l}\text { Hematopoietic } \\
\text { Transcription Factor } \\
\text { PU.1 } * *\end{array}$ & SPI1 & CAGGCGTGCAAAATGGAAG & GTAATGGTCGCTATGGCTCTC & $60^{\circ} \mathrm{C} 20^{\prime \prime}$ & $147 \mathrm{bp}$ & NM_003120 \\
\hline Interleukin $6 * *$ & IL6 & GCAGATGAGTACAAAAGTCCTGA & TTCTGTGCCTGCAGCTTC & $60^{\circ} \mathrm{C} 20^{\prime \prime}$ & $120 \mathrm{bp}$ & NM_000600 \\
\hline Interleukin 1 betaI $* * *$ & IL1b & \multicolumn{2}{|c|}{ Hs_IL1B_1_SG } & $55^{\circ} \mathrm{C} 20^{\prime \prime}$ & $117 \mathrm{bp}$ & NM_000576 \\
\hline $\begin{array}{l}\text { Matrix } \\
\text { metallopeptidase } 1 * *\end{array}$ & MMP1 & GACAGAGATGAAGTCCGGTTT & GCCAAAGGAGCTGTAGATGTC & $60^{\circ} \mathrm{C} 20^{\prime \prime}$ & $102 \mathrm{bp}$ & NM_001145938 \\
\hline $\begin{array}{l}\text { Matrix } \\
\text { metallopeptidase } \\
13 \mathrm{M}^{* *}\end{array}$ & MMP13 & AGCCACTTTATGCTTCCTGA & TGGCATCAAGGGATAAGGAAG & $60^{\circ} \mathrm{C} 20^{\prime \prime}$ & $130 \mathrm{bp}$ & NM_002427 \\
\hline
\end{tabular}

* Designed with Primer Blast (http://www.ncbi.nlm.nih.gov/tools/primer-blast/).

** Prime Time assay IDT.

***QuantiTect Primer Assay - Qiagen.

- denaturation at $95^{\circ} \mathrm{C}$ for $15 \mathrm{~min}$;

- 30 to 50 cycles of amplification $\left(95^{\circ} \mathrm{C} 15 \mathrm{~s}\right.$, appropriate annealing temperature for each target gene and $72^{\circ} \mathrm{C}$ for $20 \mathrm{~s}$ );

- melting curve analysis to check for amplicon specificity.

Data were collected using the LightCycler Software 4.1. Gene expression levels of the target genes were calculated by normalization to the reference gene GAPDH, using the comparative threshold method $(\Delta \mathrm{Ct})$, so that the $\Delta \mathrm{Ct}$ value is lower the more the gene is expressed.

\section{Histological and immunohistochemical analyses}

Bone tissue specimens were fixed in $10 \%$ buffered formalin and decalcified in a nitric/formic acid solution. When decalcification was complete (about 5-7 days), the samples were dehydrated in a graded series of alcohols and then processed for paraffin embedding. Five-micrometerthick sections were obtained by a Microm HM340E (Microm International $\mathrm{GmbH}$, Heidelberg, Germany) and stained with haematoxilin/eosin (H/E) or processed for immunohistochemical analysis using rabbit antihuman keratin 18 Monoclonal antibody (clone SP69) and rabbit anti-human keratin 8 polyclonal antibody (Spring Bioscience, Pleasanton, CA, USA). To reduce intra-bone variation, we evaluated at least three sections throughout the biopsy at $30 \mu \mathrm{m}$ intervals. Ten microscopic fields per section (magnification $40 \times$ or $80 \times$ ) were randomly observed with an optic microscope (Olympus-BX51,
Germany) connected to an image analyzer system (LeicaQwin, UK).

\section{TRAP staining to visualize osteoclast activity}

Tissue sections were deparaffinised and TRAP staining was performed using a commercial acid phosphatase leucocyte kit (Sigma, St Louis, MO). In the bone samples, ten areas (magnification $\times 20$ ) were randomly observed with an optic microscope (OlympusBX51, Germany) connected to an image analyzer system (Leica-Qwin, UK) and TRAP positive cells in each area were observed.

\section{Statistical analysis}

Statistical analysis was performed using the $\mathrm{IBM}^{\circledR}$ SPSS $^{\circledR}$ Statistics v.23 software. Data are reported as Mean \pm SD at a significance level of $p<0.05$. The Kolmogorov Smirnov test was performed to test normality of the variables. The General Linear Model (GLM) with adjusted Sidak's multiple comparison test with 'culture conditions' (normoxia or hypoxia) and 'presence of cancer cells' (with or without) as fixed effects was performed to assess the differences between factors on micro-CT results within female and male bone specimens, separately. The differences between hypoxic and normoxic culture conditions in terms of cell viability were analyzed by using Student's $t$-test within female and male bone specimens, separately. 


\section{ACKNOWLEDGMENTS AND FUNDING}

This work was partially supported by grants from Rizzoli Orthopedic Institute (Ricerca Corrente), $5 \times 1000$ 2013 Project "Sviluppo e validazione di modelli alternativi e complementari in vitro (intelligent testing strategy) in ortopedia e traumatologia", the Operational Programme ERDF 2007-2013 in the region Emilia- Romagna: Activity The 1.1 "Creation of technology centers for Industrial research and technological transfer" and by the Project: "Tumor microenvironment: potential role of osteoporosis in the development of bone metastases. In vitro and in vivo studies", programma di ricerca Regione-Università 2010 2012 Area 1-“Bando Giovani Ricercatori”.

\section{CONFLICTS OF INTEREST}

All the authors declare that they have not conflicts of interest.

\section{REFERENCES}

1. Weilbaecher KN, Guise TA, McCauley LK. Cancer to bone: a fatal attraction. Nat Rev Cancer. 2011; 11:411-25. doi: 10.1038/nrc3055.

2. Jung K, Lein M. Bone turnover markers in serum and urine as diagnostic, prognostic and monitoring biomarkers of bone metastasis. Biochim Biophys Acta. 2014; 1846:425-38. doi: 10.1016/j.bbcan.2014.09.001.

3. Ell B, Kang Y. Transcriptional control of cancer metastasis. Trends Cell Biol. 2013; 23:603-11. doi: 10.1016/j. tcb.2013.06.001.

4. Tagliaferri P, Rossi M, Di Martino MT, Amodio N, Leone E, Gulla A, Neri A, Tassone P. Promises and challenges of MicroRNA-based treatment of multiple myeloma. Curr Cancer Drug Targets. 2012; 12:838-46. doi: 10.2174/156800912802429355.

5. Salamanna F, Pagani S, Maglio M, Borsari V, Giavaresi G, Martelli AM, Buontempo F, Fini M. Estrogen-deficient osteoporosis enhances the recruitment and activity of osteoclasts by breast cancer cells. Histol Histopathol. 2015.

6. Pagani S, Fini M, Giavaresi G, Salamanna F, Borsari V. The active role of osteoporosis in the interaction between osteoblasts and bone metastases. Bone. 2015; 79:176-82. doi: 0.1016/j.bone.2015.06.002.

7. Salamanna F, Martini L, Pagani S, Parrilli A, Giavaresi G, Maltarello MC, Fini M. MRMT-1 rat breast carcinoma cells and models of bone metastases: improvement of an in vitro system to mimic the in vivo condition. Acta Histochem. 2013; 115:76-85. doi: 10.1016/j.acthis.2012.05.005.

8. Nyga A, Cheema U, Loizidou M. 3D tumour models: novel in vitro approaches to cancer studies. J Cell Commun Signal. 2011; 5:239-48. doi: 10.1007/s12079-011-0132-4.

9. Griffith LG, Naughton G. Tissue engineering-current challenges and expanding opportunities. Science. 2002; 295:1009-14. doi:10.1126/science.1069210.
10. Kim JB. Three-dimensional tissue culture models in cancer biology. Semin Cancer Biol. 2005; 15:365-77. doi:10.1016/j.bbcan.2014.09.001.

11. Mercier NR, Costantino HR, Tracy MA, Bonassar LJ. A novel injectable approach for cartilage formation in vivo using PLG microspheres. Ann Biomed Eng. 2004; 32:418-29.

12. Thein-Han WW, Misra RD. Biomimetic chitosannanohydroxyapatite composite scaffolds for bone tissue engineering. Acta Biomater. 2009; 5:1182-97. doi: 10.1016/j.actbio.2008.11.025.

13. Alsberg E, Anderson KW, Albeiruti A, Franceschi RT, Mooney DJ. Cell-interactive alginate hydrogels for bone tissue engineering. J Dent Res. 2001; 80:2025-9. doi: 10.1177/00220345010800111501

14. Glowacki J, Mizuno S. Collagen scaffolds for tissue engineering. Biopolymers. 2008;89:338-44. doi: 10.1002/ bip. 20871.

15. Fischbach $\mathrm{C}$, Chen $\mathrm{R}$, Matsumoto $\mathrm{T}$, Schmelzle $\mathrm{T}$, Brugge JS, Polverini PJ, Mooney DJ. Engineering tumors with 3D scaffolds. Nat Methods. 2007; 4:855-60. doi:10.1038/nmeth1085.

16. Xu F, Burg KJ. Three-dimensional polymeric systems for cancer cell studies. Cytotechnology. 2007; 54:135-43. doi: 10.1007/s10616-007-9065-4.

17. Nordstrand A, Nilsson J, Tieva A, Wikström P, Lerner UH, Widmark A. Establishment and validation of an in vitro co-culture model to study the interactions between bone and prostate cancer cells. Clin Exp Metastasis. 2009; 26:945-53. doi: 10.1007/s10585-009-9285-4.

18. Schiller KR, Zillhardt MR, Alley J, Borjesson DL, Beitz AJ, Mauro LJ. Secretion of MCP-1 and other paracrine factors in a novel tumor-bone coculture model. BMC Cancer. 2009; 9:45. doi: 10.1186/1471-2407-9-45.

19. Bussard KM, Okita N, Sharkey N, Neuberger T, Webb A, Mastro AM. Localization of osteoblast inflammatory cytokines MCP-1 and VEGF to the matrix of the trabecula of the femur, a target area for metastatic breast cancer cell colonization. Clin Exp Metastasis. 2010; 27:331-40. doi: 10.1007/s10585-010-9330-3.

20. Sosnoski DM, Krishnan V, Kraemer WJ, DunnLewis C, Mastro AM. Changes in Cytokines of the Bone Microenvironment during Breast Cancer Metastasis. Int J Breast Cancer. 2012; 2012:160265. doi: 10.1155/2012/160265.

21. Hicks KO, Pruijn FB, Secomb TW, Hay MP, Hsu R, Brown JM, Denny WA, Dewhirst MW, Wilson WR. Use of three-dimensional tissue cultures to model extravascular transport and predict in vivo activity of hypoxia-targeted anticancer drugs. J Natl Cancer Inst. 2006; 98:1118-28. doi: 10.1093/jnci/djj306.

22. Curtin P, Youm H, Salih E. Three-dimensional cancer-bone metastasis model using ex-vivo co-cultures of live calvarial bones and cancer cells. Biomaterials. 2012; 33:1065-78. doi: 10.1016/j.biomaterials.2011.10.046.

23. Kuperwasser C, Dessain S, Bierbaum BE, Garnet D, Sperandio K, Gauvin GP Naber SP, Weinberg RA, 
Rosenblatt M. A mouse model of human breast cancer metastasis to human bone. Cancer Res. 2005; 65:6130-8. doi: 10.1158/0008-5472.CAN-04-1408.

24. Holen I, Nutter F, Wilkinson JM, Evans CA, Avgoustou P, Ottewell PD. Human breast cancer bone metastasis in vitro and in vivo: a novel 3D model system for studies of tumour cell-bone cell interactions. Clin Exp Metastasis. 2015; 32:689-702. doi: 10.1007/s10585-015-9737-y.

25. Contag CH, Lie WR, Bammer MC, Hardy JW, Schmidt TL, Maloney WJ, King BL. Monitoring dynamic interactions between breast cancer cells and human bone tissue in a co-culture model. Mol Imaging Biol. 2014; 16:158-66. doi: 10.1007/s11307-013-0685-0.

26. Hirao M, Hashimoto J, Yamasaki N, Ando W, Tsuboi H, Myoui A, Yoshikawa H. Oxygen tension is an important mediator of the transformation of osteoblasts to osteocytes. J Bone Miner Metab. 2007; 25:266-76.

27. Sottnik JL, Keller ET. Understanding and targeting osteoclastic activity in prostate cancer bone metastases. Curr Mol Med. 2013; 13:626-39.

28. Schulze J, Weber K, Baranowsky A, Streichert T, Lange T, Spiro AS, Albers J, Seitz S, Zustin J, Amling M, Fehse B, Schinke T. p65-Dependent production of interleukin-1 $\beta$ by osteolytic prostate cancer cells causes an induction of chemokine expression in osteoblasts. Cancer Lett. 2012; 317:106-13. doi: 10.1016/j.canlet.2011.11.016.

29. Lee YM, Fujikado N, Manaka H, Yasuda H, Iwakura Y. IL-1 plays an important role in the bone metabolism under physiological conditions. Int Immunol. 2010; 22:805-16. doi: 10.1093/intimm/dxq431.

30. Trebec-Reynolds DP, Voronov I, Heersche JN, Manolson MF. IL-1alpha and IL-1beta have different effects on formation and activity of large osteoclasts. J Cell Biochem. 2010;109:975-82. doi: 10.1002/jcb.22476.

31. Tondravi MM, McKercher SR, Anderson K, Erdmann JM, Quiroz M, Maki R, Teitelbaum SL. Osteopetrosis in mice lacking haematopoietic transcription factor PU.1. Nature. 1997; 386:81-4.

32. Cicek M, Vrabel A, Sturchio C, Pederson L, Hawse JR, Subramaniam M, Spelsberg TC, Oursler MJ. TGF- $\beta$ inducible early gene 1 regulates osteoclast differentiation and survival by mediating the NFATc1, AKT, and MEK/ ERK signaling pathways. PLoS One. 2011; 6:e17522. doi: 10.1371/journal.pone.0017522.
33. Grigoriadis AE, Wang ZQ, Cecchini MG, Hofstetter W, Felix R, Fleisch HA, Wagner EF. c-Fos: a key regulator of osteoclast-macrophage lineage determination and bone remodeling. Science. 1994; 266:443-8.

34. Cappellen D, Luong-Nguyen NH, Bongiovanni S, Grenet O, Wanke C, Susa M. Transcriptional program of mouse osteoclast differentiation governed by the macrophage colony-stimulating factor and the ligand for the receptor activator of NFkappa B. J Biol Chem. 2002; 277:21971-82.

35. Zhang Q, Guo R, Lu Y, Zhao L, Zhou Q, Schwarz EM, Huang J, Chen D, Jin ZG, Boyce BF, Xing L. VEGF-C, a lymphatic growth factor, is a RANKL target gene in osteoclasts that enhances osteoclastic bone resorption through an autocrine mechanism. J Biol Chem. 2008; 283:13491-9. doi: 10.1074/jbc.M708055200.

36. Boyle WJ, Simonet WS, Lacey DL. Osteoclast differentiation and activation. Nature. 2003; 423:337-42.

37. Kang JH, Ko HM, Moon JS, Yoo HI, Jung JY, Kim MS, Koh JT, Kim WJ, Kim SH. Osteoprotegerin expressed by osteoclasts: an autoregulator of osteoclastogenesis. J Dent Res. 2014; 93:1116-23. doi: 10.1177/0022034514552677.

38. Condeelis J, Pollard JW. Macrophages: obligate partners for tumor cell migration, invasion, and metastasis. Cell. 2006; 124:263-6. doi:10.1016/j.cell.2006.01.007

39. Coussens LM, Werb Z. Inflammation and cancer. Nature. 2002; 420:860-7. doi: 10.1038/nature01322

40. Sabino MA, Ghilardi JR, Jongen JL, Keyser CP, Luger NM, Mach DB, Peters CM, Rogers SD, Schwei MJ, de Felipe C, Mantyh PW. Simultaneous reduction in cancer pain, bone destruction, and tumor growth by selective inhibition of cyclooxygenase-2. Cancer Res. 2002; 62:7343-9.

41. Miyaura C, Inada M, Suzawa T, Sugimoto Y, Ushikubi F, Ichikawa A, Narumiya S, Suda T. Impaired bone resorption to prostaglandin E2 in prostaglandin E receptor EP4knockout mice. J Biol Chem. 2000; 275:19819-23. doi: 10.1074/jbc.M002079200.

42. Doroudinia A, Colletti PM. Bone Mineral Measurements. Clin Nucl Med. 2015; 40:647-57. doi: 10.1097/ RLU.0000000000000860.

43. Foerster R, Eisele C, Bruckner T, Bostel T, Schlampp I, Wolf R, Debus J, Rief H. Bone density as a marker for local response to radiotherapy of spinal bone metastases in women with breast cancer: a retrospective analysis. Radiat Oncol. 2015; 10:62. doi: 10.1186/s13014-015-0368. 